\title{
Review
}

\section{The Satellite Cell at 60: The Foundation Years}

\author{
Elise N. Engquist and Peter S. Zammit ${ }^{1, *}$ \\ Randall Centre for Cell and Molecular Biophysics, King's College London, Guy's Campus, London, SE1 1UL, \\ UK
}

\begin{abstract}
The resident stem cell for skeletal muscle is the satellite cell. On the 50th anniversary of its discovery in 1961, we described the history of skeletal muscle research and the seminal findings made during the first 20 years in the life of the satellite cell (Scharner and Zammit 2011, doi: 10.1186/2044-5040-1-28). These studies established the satellite cell as the source of myoblasts for growth and regeneration of skeletal muscle. Now on the 60th anniversary, we highlight breakthroughs in the second phase of satellite cell research from 1980 to 2000. These include technical innovations such as isolation of primary satellite cells and viable muscle fibres complete with satellite cells in their niche, together with generation of many useful reagents including genetically modified organisms and antibodies still in use today. New methodologies were combined with description of endogenous satellite cells markers, notably Pax7. Discovery of the muscle regulatory factors Myf5, MyoD, myogenin, and MRF4 in the late 1980s revolutionized understanding of the control of both developmental and regerenative myogenesis. Emergence of genetic lineage markers facilitated identification of satellite cells in situ, and also empowered transplantation studies to examine satellite cell function. Finally, satellite cell heterogeneity and the supportive role of nonsatellite cell types in muscle regeneration were described. These major advances in methodology and in understanding satellite cell biology provided further foundations for the dramatic escalation of work on muscle stem cells in the 21 st century.
\end{abstract}

Keywords: Satellite cell, skeletal muscle, muscle regulatory factors, muscle regeneration, myofibre, Pax7, MyoD, Myf5

\section{INTRODUCTION}

Skeletal muscle is composed of syncytial muscle fibres in which many myonuclei control a common cytoplasm containing the sarcomeres that generate force by contraction. Muscle fibres are formed by fusion of mononuclear myoblasts into myotubes, which then grow by addition of further myonuclei from myoblast fusion and hypertrophy. Myonuclei are post mitotic, so repair and regeneration of skeletal muscle fibres requires a source of myoblasts to either fuse to existing muscle fibres to donate new myonuclei, or fuse together for de novo myofibre formation.

\footnotetext{
*Correspondence to: Randall Centre for Cell and Molecular Biophysics, King's College London, Guy's Campus, London, SE1 1UL, UK. E-mail: peter.zammit@kcl.ac.uk.

${ }^{1}$ ORCID iD: 0000-0001-9562-3072
}

The muscle satellite cell is accepted as the predominant resident stem cell source supplying myoblasts to postnatal skeletal muscle $[1,2]$.

On the 50th anniversary of the discovery of the satellite cell by Alexander Mauro [3] (and Bernard Katz on intrafusal myofibres [4]) in 1961, we first discussed the early studies in skeletal muscle growth and regeneration, starting in the 19th century when most publications were in scholarly German. We then considered the key findings up to $\sim 1980$, by which time the satellite cell had generally become accepted as the preeminent source of myoblasts for growth and regeneration of skeletal muscle [5].

In this companion review in the 60th year of the satellite cell, we focus on the second phase of satellite cell research from 1980 to 2000, which includes some of the major discoveries that laid further foundations for satellite cell research. We start by highlighting 
the technical innovations for purification of primary myogenic cells [6], and isolation of viable muscle fibres complete with satellite cells in their niche [7, 8]. This is followed by discussion of endogenous markers that identify quiescent satellite cells in situ at the light microscopic level, the most important being the transcription factor Pax7 [9] (especially since modification of the Pax7 locus allows specific targeting of satellite cells [1]). The seminal discovery of the muscle regulatory factor (MRF) family of transcription factors helped explain muscle formation and linked control of developmental and regenerative myogenesis [10], as well as provide important tools such as excellent antibodies to MyoD [11] and myogenin [12]. Genetic modification to explore the regulation, expression and role of myogenic genes further enhanced understanding of satellite cell function [10]. Genetic engineering also delivered early lineage markers such as the Myf $5^{\text {nlac } Z}$ allele [13] and 3F-nlacZ-E transgene [14], which facilitated identification of satellite cells in situ [15]. Importantly, such lineage markers also allowed cell fate to be discerned following transplantation, permitting the full potential of grafting experiments to be realized. This ultimately led to the designation of satellite cells as stem cells in 2005 [16], with subsequent studies confirming this classification $[17,18]$. Finally, early work on satellite cell heterogeneity and the support of muscle regeneration by non-satellite cells are discussed, along with initiation of the Satellite Cell Conference series in 1998. Important in themselves, studies in this second phase of satellite cell research also underpinned the surge of investigation in muscle stem cells in the 21st century [19].

\section{METHODS TO OBTAIN SATELLITE CELLS}

Generation of clonal myogenic cell lines allowed the study of myogenesis to become more accessible, but many of these early lines were derived from developing muscle [5]. A number of clonal myogenic lines derived from adult mouse muscle were developed in the late 1970s/early 1980 s that were more likely to be satellite cell in origin. Of these, the $\mathrm{C} 2$ cell line is probably the best known, derived by Yaffe and Saxel in 1977 [20], which was later subcloned to generate the $\mathrm{C} 2 \mathrm{C} 12$ cell line [21], which is still widely used. Other notable satellite cell-derived mouse lines include MM14 and its derivatives [22, 23] and $\mathrm{H}$ $2 \mathrm{~Kb}$-tsA58 myoblast clones isolated from transgenic mice carrying a thermolabile T antigen [24]. Conditional immortalization now allows routine creation of myoblast clones, including from human e.g. [25]. Those isolated from patients provide versatile disease models, with a good example being the isogenic clones with/without the pathogenic mutation derived from a mosaic FSHD patient [26].

Collecting a representative population of primary satellite cells from adult tissue was more problematic however, and much early investigation was performed using embryonic/foetal myoblasts, for example into the role of growth factors in myogenesis (for contemporary review see [27]). While trypsin, pronase, collagenase, papain or ficin could be used to liberate myoblasts from embryonic chick and foetal rat muscle, Richard Bischoff found that only trypsin and pronase proved effective in adult rat $[28,29]$. Thus adult muscle needed proteases to release satellite cells from the basal lamina of the myofibre. Additionally, although a high proportion of myogenic cells were obtained, fibroblasts would often overgrow the cultures [28, 29]. In 1981, Blau and Webster optimised pre-plating to enrich populations of myoblasts from adult human muscle tissue [30] and from patients with various diseases [31]. Fibroblastic cells more readily adhere to non-coated cell culture plates so could be removed, allowing the less-adherent myogenic cells to be concentrated and collected. Pre-plating remains part of some protocols e.g. [32].

A drawback of pre-plating enrichment strategies was that cell debris and myofibre fragments remained in the cell suspension, preventing analysis immediately following isolation. Combination of pronase digestion, differential centrifugation and pre-plating improved yield, permitting Ron Allen and colleagues to show that fibroblast growth factor (FGF) promoted rat satellite cell proliferation [33, 34]. Percoll fractionation, where myogenic cells occupy a specific layer following density centrifugation, removed additional debris, producing an enriched myogenic population [35, 36], although not all contaminating cells were removed [37]. However, these methods had an important caveat, that there was "no way of clearly identifying the myogenic precursor cells isolated from the adult muscle as the 'classical' satellite cells" [35].

Advent of fluorescence-activated cell sorting (FACS) was a game changing technology for purifying primary myogenic cells from adult muscle. Antibodies that bound satellite cells (e.g. against N-CAM) allowed a relatively pure population of myogenic cells to be obtained from adult muscle [6]. 
FACS remains a standard to isolate primary satellite cells, using a combination of endogenous antigens for positive and negative selection [38], and/or genetic modifications such as Pax7-ZsGreen [39]. A drawback of FACS is that it is somewhat technical and does require expensive equipment and skilled support, but bench-top methods such as magnetic bead cell sorting are also effective e.g. [40]. These techniques facilitated examination of a more representative group of primary myoblasts, rather than the greatly expanded progeny of a few select clones.

\section{ISOLATION OF SATELLITE CELLS IN THEIR NICHE ON A MYOFIBRE}

To better investigate satellite cells and muscle regeneration, early studies of Irwin Konigsberg et al. [41, 42] and Richard Bischoff [43] had physically peeled myofibres from muscle fragments "much the same way that a piece of adhesive tape is removed from a surface" [43]. Juvenile quail, human [41, 42] and adult rat muscle [43] all yielded muscle fibres that could then be cultured to produce myogenic cells capable of differentiating into myotubes. Pertinently though, it was noted that while myogenic cells emigrated from some myofibres of younger animals, cells only emerged from the cut ends of adult myofibres, or if the basal lamina was deliberately damaged [29]. While such physical separation from adult muscle left the basal lamina intact, it often damaged the myofibre [29]. This provided a useful tool to study myofibre repair since the satellite cells were unable to traverse the basal lamina and so were retained near the muscle fibre [43], giving a relatively faithful model of events observed later by in vivo imaging of muscle repair [44].

Kopriwa and Moss had shown that muscle fibres could be liberated from growing rats with collagenase, using collagenase digestion of fixed strips of tibialis anterior to identify cells that had been dividing in vivo [45]. Collagenase and protease digestion of unfixed frog cutaneous pectoris by Betz and Sakmann isolated single muscle fibres with satellite cells that were beginning to detach [46]. Bekoff and Betz then employed digestion of unfixed rat flexor digitorum brevis (FDB) muscle with collagenase, followed by mechanical trituration to separate live myofibres, before plating the suspension in collagencoated dishes [47] (Fig. 1A). However, the majority of myofibres remained in suspension where they formed clumps, meaning that only the small number of mus- cle fibres that adhered to the dish could be analysed. Primarily interested in using myofibres to investigate the effects of denervation such as acetylcholine sensitivity, conditions were not optimized for satellite cells. Dissociated myofibres were not separated from other cell types, and it was noted that the few adherent muscle fibres appeared to be attached by mononuclear cells, which they suspected were fibroblasts [47].

With more focus on satellite cell biology, Rubin et al. reported that a layer of irradiated fibroblasts improved the adherence of rat FDB muscle fibres, which then allowed satellite cells to form myotubes on the culture substrate [48]. Nomarski (differential) interference contrast microscopy was used by Lawrence and Mauro to observe living satellite cells at the light microscope level on a single layer of myofibres from the frog cutaneous pectoris [49]. Application of Nomarski interference to isolated myofibres allowed Cull-Candy et al. to describe live frog satellite cells as fusiform with long fine processes, and typically orientated parallel to the axis of the muscle fibre [50]. Crucially, this approach permitted satellite cell distribution and number to be determined, revealing that satellite cells were arranged with neither pattern nor at consistent density along a muscle fibre, with 4-14 per lumbricalis myofibre.

Bischoff built upon the method of Bekoff and Betz [47] to develop a technique to specifically retain satellite cells on muscle fibres ex vivo [8]. In his modified protocol, Bischoff removed the trypsin-like peptidase clostripain from the collagenase digestion medium, noting that the basal lamina then remained intact using immunolabeling for laminin. A sedimentation step prior to plating was also introduced that purified fibres from tissue debris and mononuclear cells. Difficulty in separating longer muscle fibres confined his studies to muscles containing shorter myofibres such as the FDB of the rat. This protocol meant that satellite cells remained viable for several days ex vivo in their native niche on a myofibre that had adhered to the collagen substrate, allowing recovery of satellite cells from an altered, rounded morphology immediately following isolation. Bischoff investigated factors influencing satellite cell proliferation, as assessed by incorporation of tritiated thymidine and autoradiography. This revealed that chicken embryo extract (CEE) or extract from crushed adult muscle stimulated satellite cell proliferation $[8,51]$ (Fig. 1B).

Yablonka-Reuveni and Rivera 1994 then expanded the potential of the isolated muscle fibre model by 

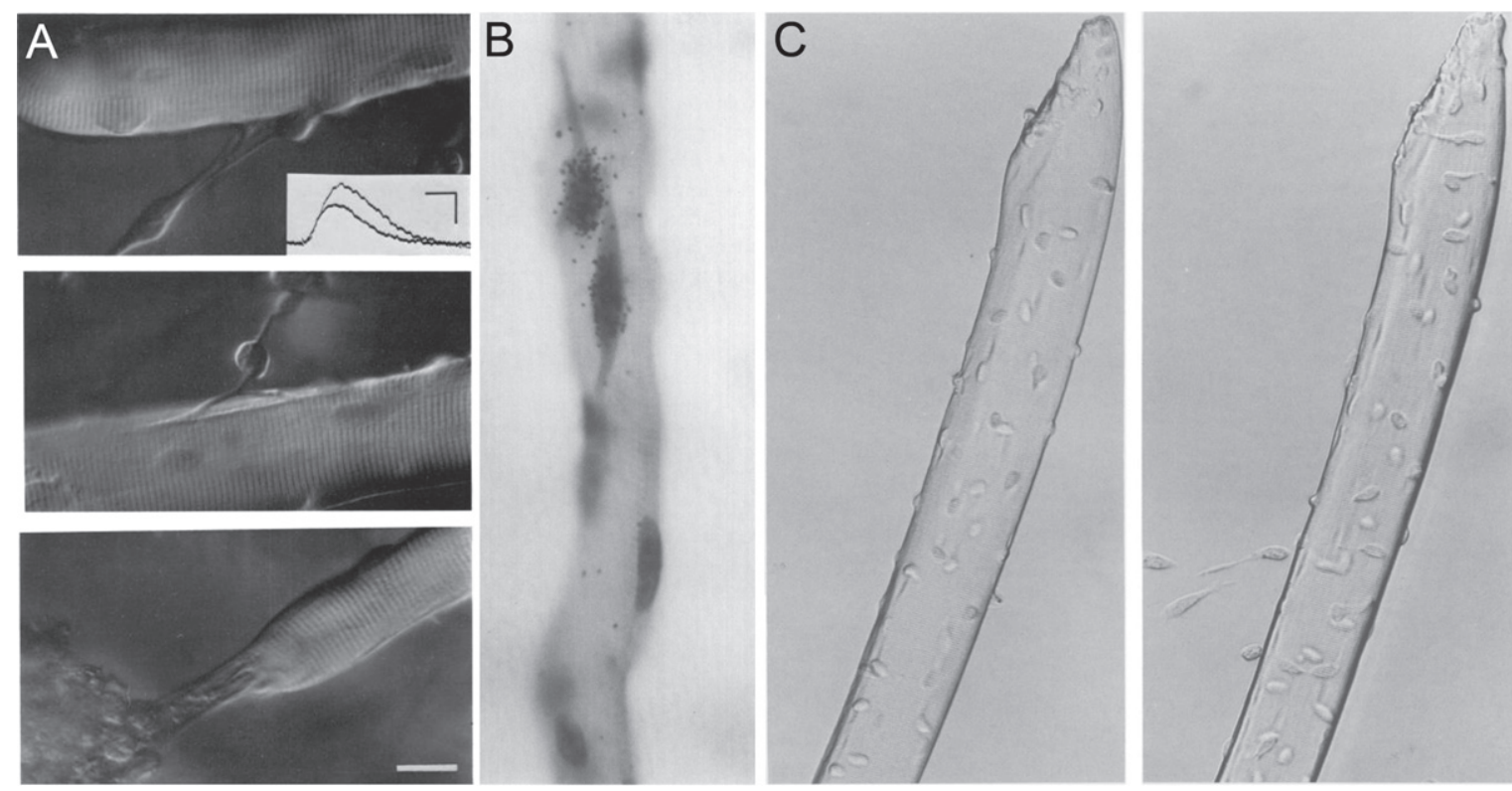

Fig. 1. Isolation of muscle fibres to obtain satellite cells in their niche. (A) Three examples of muscle fibres isolated from the flexor digitorum brevis of adult rat and cultured ex vivo for 6-9 days, exhibiting attached cellular processes, from Bekoff and Betz, 1977 [47]. The authors were interested in modeling denervation, with this figure informing on acetylcholine sensitivity of isolated fibres using an intracellular electrode (inset). Scale bar represents $20 \mu \mathrm{m}$. (B) Muscle fibre from the flexor digitorum brevis of an adult rat from Bischoff, 1986 [8], isolated using a protocol optimized from Bekoff and Betz [47] to better preserve the satellite cell niche. Bischoff was investigating proliferation of satellite cells on isolated myofibres ex vivo and the effects of mitogens. Proliferation was measured via incorporation of tritriated thymidine and autoradiography (generating black grains of silver over radioactive areas), with Gill's haematoxylin used to identify nuclei. The strongest effect on proliferation was from addition of chicken embryo extract (pictured here), followed by FGF. Magnification is x660. (C) Plated isolated myofibres from the extensor digitorum longus of an adult mouse with migrating satellite cells after 2 hours (left) and 24 hours (right) ex vivo, from Rosenblatt et al., 1995 [7]. The protocol was modified to allow isolation of longer myofibres from larger rodent muscles. Over time, satellite cells detach from the surface of the myofibre and proliferate on the matrigel substrate. Magnification is x 300 . Images as originally published but may have been cropped, and panel labels have been amended/rearranged/added.

immunolabelling the actual satellite cells in situ on rat FDB myofibres, monitoring changes occurring over several days ex vivo [52]. Using a panel of antibodies, they described the temporal sequence of satellite cell activation, proliferation and differentiation (see below), and also noted how FGF stimulated satellite cell proliferation $[52,53]$.

In 1995, the Partridge group made further improvements to produce a definitive method to isolate myofibres from larger rodent muscles (extensor digitorum longus (EDL), soleus and tibialis anterior), and to then separate satellite cells/myogenic precursors from the myofibres [7]. While proteases had been used previously to digest the basal lamina to liberate myogenic cells [28], a major modification included defining an optimum range of protease content in the collagenase used to digest the muscle. Other innovations included cleaning by serially transferring to fresh medium, and gentle trituration using a series of heat-polished pipettes with decreasing apertures, which facilitated survival of the longer muscle fibres that were usually lost/damaged by a sedimentation step. Repeating digestion after removal of the exterior-most myofibres allowed isolation of interior myofibres from bulkier muscles. Another tweak was use of Matrigel, extracted from EngelbrethHolm-Swarm mouse sarcomas [54, 55]. Matrigel is a solubilized preparation rich in extracellular membrane factors including laminin, nidogen, collagen IV and heparan sulfate proteoglycans, available with, or depleted of, growth factors. Matrigel had been shown to be an effective substrate for myogenesis in plated cells [56] but also facilitated attachment of isolated muscle fibres. Crucially, the muscle fibres could also be easily removed, and analysed if desired [7].

With this protocol, Rosenblatt et al. observed satellite cells detaching from adult myofibres within 24 hours of plating and adhering to the Matrigel-coated plate (Fig. 1C), indicating sufficient digestion of the basal lamina. Immunolabeling for the musclespecific intermediate filament desmin [57] revealed the purity of the satellite cell-derived myoblasts 
surrounding a myofibre. Collection of the muscle fibres then allowed determination of the muscle fibre type via Western blot and facilitated further myoblast expansion and formation of sizeable myotubes [58]. Alternatively, fixation of myofibres immediately after digestion and trituration allowed examination of nearquiescent satellite cells in their niche [15], since the isolation procedure can initiate satellite cell activation $[59,60]$.

Isolating satellite cells and muscle fibres provided new opportunities to investigate factors that drive satellite cell activation, including Hepatocyte Growth Factor (HGF) [61, 62], nitric oxide (NO) [63] and mechanical stimulation [64], and proliferation $[8,51,52]$. These techniques also facilitated exploration of differences between satellite cell populations from different fibre types [58], ages [65], dystrophic models [66] and genetically modified backgrounds [67]. Comprehensive protocols for isolation of myofibres and immunolabeling are available $[59,68-70]$.

\section{SATELLITE CELL MARKERS}

For many years following their discovery using electron microscopy, quiescent satellite cells were identified by their anatomical location between the plasmalemma of a muscle fibre and the ensheathing basal lamina. This anatomical niche was used to identify satellite cells on growing myotubes as the basal lamina forms during embryonic day (E) 18/19 of mouse development [71, 72]. However, it was found that satellite cells were likely specified before they could be distinguished on this anatomical criterion in late foetal development.

Embryonic and foetal myoblasts were known to be distinct myogenic lineages (e.g. [73]). Later, differential response of myoblast populations to a tumour promoter indicated that satellite cells also composed a separate lineage, emerging around E16/17 [74], with other characteristics such as acetylcholinesterase isoform [75] and myosin heavy chain (MyHC) content [76] after differentiation providing further support. In chicken, differences in myoblast length, initiation of DNA synthesis and MyHC isoform expression also revealed that adult satellite cells/myoblasts appeared in mid-foetal development [76-78].

The necessity to identify satellite cells on an ultrastructural criterion limited study, especially of quiescence and early activation. While general markers of cell proliferation such as PCNA [79] or incorporation of tritiated thymidine [80] could be used to identify proliferating satellite cell-derived myoblasts in mature tissues, these markers were also expressed in other proliferating cell types. Desmin was observed in the cytoplasm of proliferating satellite cells [37] and in quiescent satellite cells [81], but expression in myofibres limited its use on muscle sections [81] and isolated myofibres.

Indirect identification of satellite cells at the light microscopic level became possible when Zhang and McLennan used antibody labeling of the myofibre plasmalemma with dystrophin and the surrounding basal lamina with collagen IV to distinguish satellite cells from myonuclei [81] (Fig. 2A). Interestingly, it was also noted that dystrophin was present on some satellite cells [81], as later explored in detail [82].

Direct identification of satellite cells became possible using a monoclonal antibody against leukocyte antigen Leu-19 to visualize satellite cells by Starzinski-Powitz and colleagues [83]. Around the same time, it was revealed that Leu-19 was CD56 or neural cell adhesion molecule (N-CAM) [84], a membrane glycoprotein expressed in neural tissue and on cells surrounding the neuromuscular junction [85]. Expression of N-CAM in healthy extra-junctional adult muscle was confined to a few cells on the periphery of myofibres. Leu-19/N-CAM immunolabelling of satellite cells and myoblasts became a commonly used method for satellite cell identification and, being a surface antigen, was used for FACS-mediated isolation of satellite cells [6]. Increased numbers of $\mathrm{N}-\mathrm{CAM}$ expressing cells were noted in muscle biopsies of patients with myopathic diseases [86] and mouse models of muscular dystrophy [87].

The next important satellite cell marker was M-cadherin, a muscle-specific member of the cadherin family of calcium-dependent cell-cell adhesion factors. M-cadherin was originally identified in differentiating mouse C2 myoblasts by StarzinskiPowitz and colleagues and was also expressed by myoblasts during development [88]. M-cadherin was linked to satellite cells when a transient wave of $M$ cadherin mRNA was detected in activated satellite cells following injury [89]. Two independent groups built on this observation, publishing histological studies demonstrating that M-cadherin was on the surface of rodent quiescent satellite cells in vivo [90, 91] (Fig. 2B) but not on other cell types in uninjured muscle [90]. M-cadherin was also expressed in activated and proliferating satellite cells [89, 90]. Unfortunately, there was no effective commercial antibody available, which limited its use. 

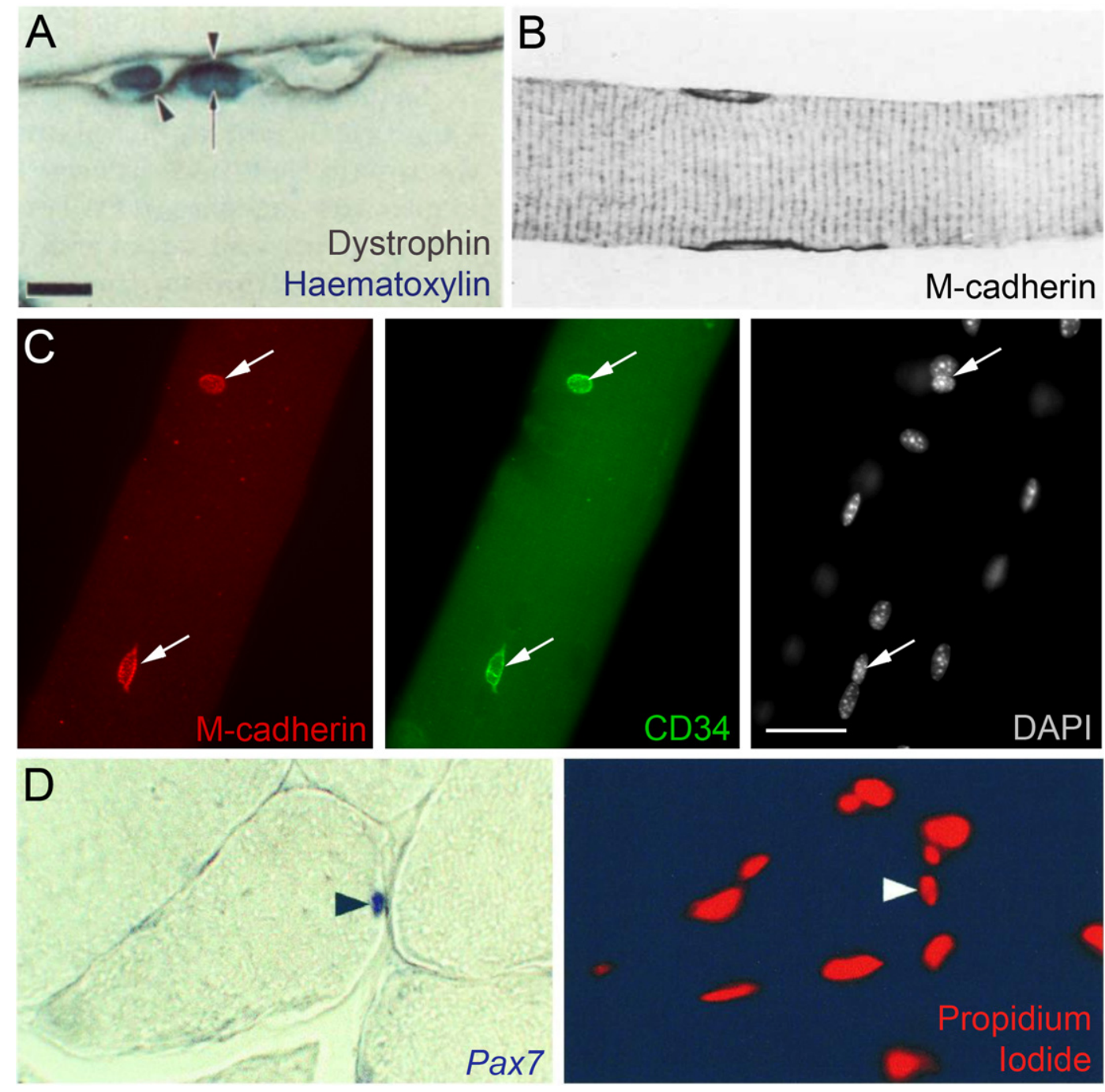

Fig. 2. Markers to identify satellite cells in situ. (A) Indirect identification of a satellite cell in a rat muscle using immunolabeling from Zhang and McLennan, 1991 [81]. Dystrophin marks the plasmalemma of the muscle fibre (arrowheads) and two nuclei are visualized using haematoxylin. Satellite cells were distinguished from other nuclei including myonuclei (arrow) by their location outside the dystrophinlabeled plasmalemma but under the basal lamina (using collagen IV immunolabelling - not shown). Scale bar equals $10 \mu \mathrm{m}$. (B) M-cadherin was shown to mark satellite cells in two papers in 1994 [90, 91], illustrated here with an image of 'normal' rat soleus muscle from Bornemann and Schmalbruch, 1994 [91]. The longitudinal section shows two satellite cells labeled with M-cadherin, which is mainly located at the satellite cell/muscle fibre interface. Magnification is x660. (C) CD34 on two satellite cells on an isolated mouse extensor digitorum longus myofibre, confirmed as satellite cells by M-cadherin co-immunolabeling (arrows), and distinct from myonuclei as revealed by DAPI nuclear counterstaining, from Beauchamp et al., 2000 [15]. Scale bar represents $30 \mu \mathrm{m}$. (D) Pax7 as a satellite cell marker from Seale et al., 2000 [9]. In situ hybridization was used to show that $\operatorname{Pax} 7 \mathrm{mRNA}$ was expressed in approximately 5\% of peripherally-located muscle nuclei in healthy adult mouse tibialis anterior muscles (left) with a propidium iodide nuclear counterstain (right). Arrowheads indicate the Pax7expressing nucleus. Magnification is $\mathrm{x} 200$. Images as originally published but may have been cropped, and the panel labels have been amended/rearranged/added.

HGF was found to induce activation of freshly isolated rat satellite cells by Allen and colleagues [61], which indicated that the HGF receptor C-Met should be expressed by quiescent satellite cells. C-Met was detected on the surface of both quiescent and activated satellite cells [61, 62, 92], with low levels also on newly formed myotubes [93] and connective tissue cells [94]. While part of an important signaling pathway for satellite cell activation and a useful candidate marker for quiescent satellite cells [53, 62], antibodies against C-Met available at the time were of variable effectiveness. 
Myocyte nuclear factor (MNF, or Foxk1) was also introduced as a satellite cell marker during this period. While $M N F$ was transiently expressed in several non-muscle cell types during development, MNF protein was restricted to the nuclei of quiescent satellite cells in adult muscle, as well as in proliferating myoblasts and the centrally located nuclei of regenerating fibres [95]. Isoforms MNF- $\alpha$ and MNF- $\beta$ were reciprocally expressed in satellite cell progeny versus quiescent satellite cells, offering the advantage of distinguishing quiescent from activated satellite cells [96].

Screening for cell surface markers known to characterise other stem cell populations, such as those in the haematopoietic system, led to our identification of CD34 as a marker of satellite cells (Fig. 2C), and demonstrated a switch in isoform upon activation [15]. A commercially available biotin-conjugated antibody revealed CD34 on quiescent satellite cells on isolated myofibres, and could also be used as part of a panel of antibodies for FACS. However, expression in other cell types (e.g. endothelial cells) made CD34 difficult to use in muscle sections [97] and it is not present on human satellite cells [98].

The turn of the century saw introduction of Paired box 7 (Pax7) as a satellite cell marker by Michael Rudnicki and colleagues [9]. Pax7, together with the closely related Pax3, were shown to be expressed during both developmental neurogenesis and myogenesis [99, 100]. Pax7 was originally identified in the satellite cell lineage through a series of cDNA subtraction hybridization studies [101]. In situ hybridization showed that Pax7 was expressed in both quiescent satellite cells (Fig. 1D) and proliferating myoblasts, before being down regulated upon myogenic differentiation [9]. At the protein level, the Fujisawa group had reported that Pax7 was present in the myotome and the nuclei of migrating myoblasts forming the trunk and limb muscle precursors in chick embryos, using their own monoclonal antibody [102]. Pax7 immunolabelling was mentioned in Seale et al. [9], with satellite cells containing nuclear-located Pax7 illustrated the following year [97]. Pax7 has become the most commonly used satellite cell marker, thanks to both its specificity and the excellent Kawakami monoclonal anti-Pax7 antibody (https://antibodyregistry.org - AB_528428) [102] available from the Developmental Studies Hybridoma Bank (DSHB) (https://dshb.biology.uiowa.edu/PAX7) that works in amphibian [103], bird [104] and mammal [9], including human $[105,106]$.
While no obvious abnormalities in myogenic precursor populations had been observed at embryonic stages in $\operatorname{Pax}^{-/-}$mice [107], there was a striking phenotype in post-natal skeletal muscle of Pax7-null animals - namely, an absence of satellite cells and a lethal loss of myofibre diameter and muscle mass [9]. This established not only the importance of Pax7 in specification of the satellite cell pool, but also the role of Pax7-expressing satellite cells in muscle growth.

Crucially, the specificity of Pax7 to satellite cells in adult muscle initiated the use of the Pax7 locus to target satellite cells, for example with eGFP [39] for identification and isolation. Targeting the Pax7 locus with Cre-ERT e.g. [108] allowed satellite cell-specific conditional recombination, permitting knockout of genes and genetic ablation of satellite cells [1].

\section{DISCOVERY OF THE MUSCLE REGULATORY FACTORS}

The late 1980s marked discovery of the four myogenic regulatory factors (MRFs) MyoD, Myf5, myogenin and MRF4 (Myf6), an event that revolutionized understanding of developmental and regenerative skeletal myogenesis [10].

The critical observation by Taylor and Jones that a DNA methyltransferase inhibitor (5-azacytidine) could convert embryonic mouse fibroblasts to a variety of other lineages, including muscle [109, 110], was later attributed to demethylation of distinct regulatory loci [111, 112]. Stable heterokaryons made from fusion of diploid human amniocytes and differentiated mouse muscle cells showed that the human nucleus could be reprogrammed to express muscle genes, indicating 'factor(s)' transferring via the cytoplasm from the differentiated mouse muscle nucleus [21]. Such observations contributed to the hypothesis that expression of specific genes can reprogram cell fate.

Davis, Weintraub and Lassar generated a cDNA library of individual loci expressed in both C2C12 myoblasts and myoblasts converted from 5 -azacytidine-treated fibroblasts, but absent in untreated fibroblasts [113]. A transcript was identified that, when transfected into 10T1/2 fibroblasts and other cell types, was sufficient to generate stable myogenic clones; the transcript was named Myogenic differentiation 1 (MyoD1, aka MyoD) [113]. 
Additional cDNA screening led to identification of myogenin due to high sequence homology to the myc domain of $M y o D$, reported separately by Wright, Sassoon and Lin [114] and Edmondson and Olson [115] in 1989. Myogenin facilitated myogenic conversion when transfected into non-muscle cells. Unlike MyoD though, endogenous myogenin was absent in proliferating myoblasts, but induced and peaked early in differentiation, shortly before fusion and expression of genes associated with muscle contraction. This led to speculation that myogenin directed the early skeletal muscle differentiation program.

Later in 1989, Braun et al. reported a third factor that they termed Myf5 [116], identified through screening transcripts expressed in foetal myoblasts that cross-hybridized with MyoD. Myf5 facilitated fibroblast-to-myoblast transdifferentiation with similar efficacy to MyoD [116].

MRF4 was the final member of the quartet, and entered the picture in September 1989 in a paper by Rhodes and Konieczny [117]. MRF4 was discovered through sequence homology to $M y o D$ in a screen against an adult rat skeletal muscle library. MRF4 could convert 10T1/2 fibroblasts to the myogenic lineage and activate $M y o D$ and myogenin in differentiating myotubes [117]. The human equivalent to MRF4 was then described, but called Myf-6 [118].

\section{MUSCLE REGULATORY FACTOR EXPRESSION IN SATELLITE CELLS}

During embryonic development, skeletal muscles of the head derive from unsegmented cranial mesoderm (comprising cranial, paraxial and precordal mesoderm). In contrast, the skeletal musculature of the body originates from transitory mesodermderived structures called somites, formed in a rostro-caudal progression in pairs flanking the neural tube $[119,120]$. Somites differentiate into the dermomyotome and sclerotome, with mesodermal cells specified as muscle precursors in the nascent myotome. Migrating cells from the dermomyotome also provide myogenic precursors to form a portion of the tongue, some neck and jaw muscles, diaphragm, trunk and limb musculature $[119,120]$ and their associated satellite cells [121].

In situ hybridization showed that Myf5 and then MRF4 were first expressed in a population of cells in the murine dermomyotome which migrate to form the myotome. These cells subsequently express myo- genin and differentiate as the first myogenic cells. $M y o D$ expression in myogenic progenitors follows that of Myf5, MRF4 and myogenin [122-124].

In adult muscle, MRF4 was the most highly expressed [124, 125], but low levels of $M y o D$ and myogenin were reported to correlate with fast and slow muscle fibre types respectively [126]. The crucial observation that MyoD and myogenin were redeployed during regenerative myogenesis was made in 1992 independently by Miranda Grounds and colleagues [127] (Fig. 3A) and Fuchtbauer \& Westphal [128]. MyoD expression was noted in mononucleated cells in sections of regenerating muscle by $4-8$ hours after acute crush injury, and then later in myotubes [127, 128]. These studies showed that the control of developmental and regenerative myogenesis employed similar regulatory pathways.

RT-PCR for MRF expression in plated adult rat satellite cells ex vivo revealed that $M y o D$ was expressed first at around 12 hours and before proliferation, followed by Myf5 and MRF4 by 48 hours, and myogenin from 72 hours, concomitant with the first evidence of differentiation [129], with similar dynamics for $M y o D$ and myogenin observed in Xenopus [130]. MRFs were not detected in quiescent satellite cells (although the Myf5 locus was later shown to be active [15]).

At the protein level, myogenic cells isolated from embryonic, foetal and newborn mice expressed the four MRFs with similar dynamics. MyoD appeared first followed by a transient wave of myogenin accompanying the onset of myotube formation, with MyoD and myogenin present in more cells than Myf5 or MRF4 [131]. Immunolabelling of satellite cells maintained in their niche on isolated myofibres ex vivo by Yablonka-Reuveni and Rivera elegantly showed the temporal progression of satellite cell myogenesis with MyoD and PCNA expressed within 2 days, then declining as myogenin and $\mathrm{MyHC}$ were expressed [52] (Fig. 3B and C). Interestingly, it was later shown that both Myf5 and MyoD levels were independently regulated through the cell cycle [132, 133].

These early studies provided the canonical markers and some of the antibodies still widely used to track the stages of regenerative myogenesis. Notable are monoclonal anti-MyoD clone 5.8A (AB_627978) [11], monoclonal anti-myogenin clone F5D (AB_2146602) $[12,134]$ and monoclonal antimyosin heavy chain II clone MF20 (AB_2147781) [135], the latter two available from the DSHB (https://dshb.biology.uiowa.edu). 

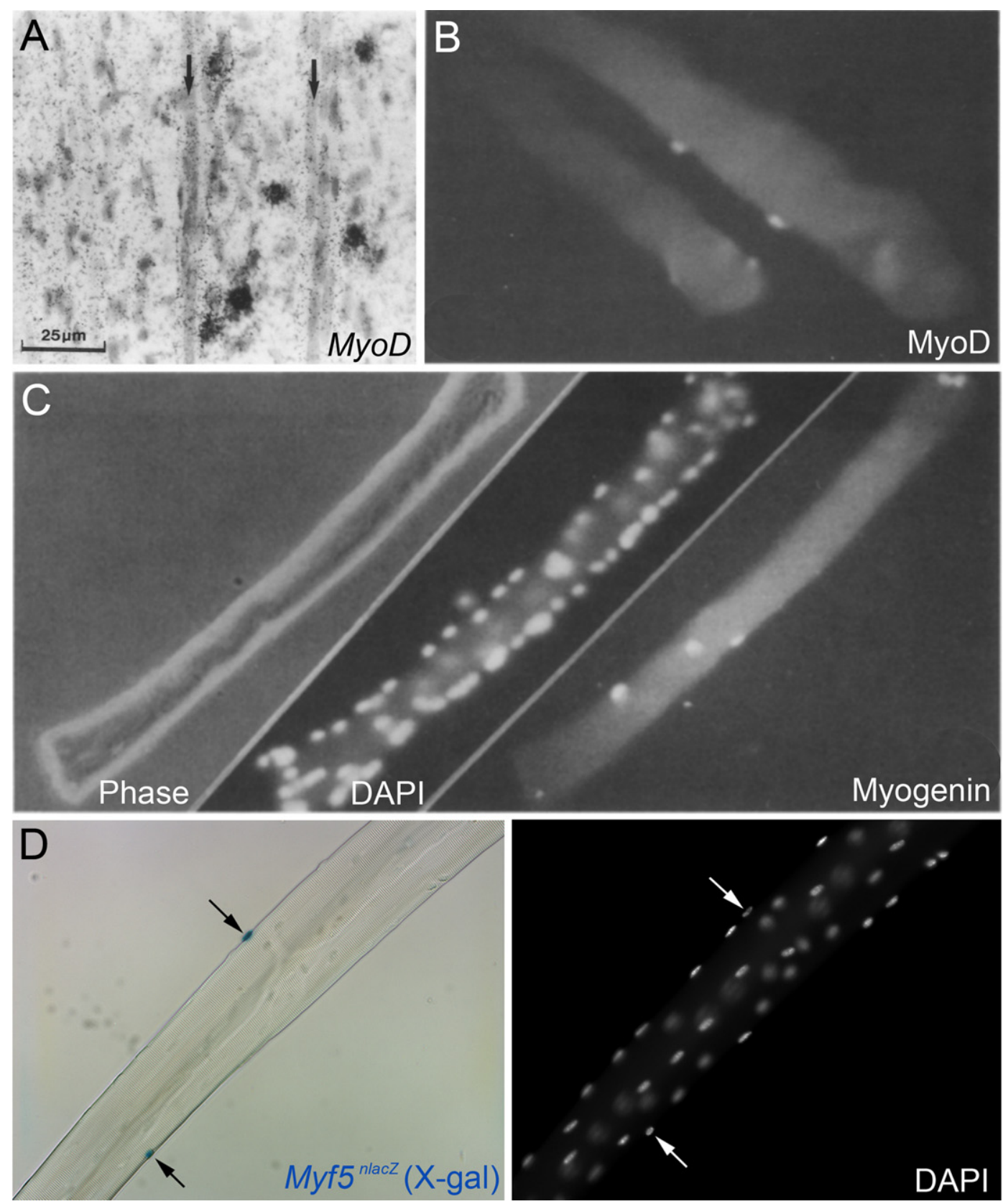

Fig. 3. Myogenic regulatory factor expression in regenerating muscle and satellite cells. (A) In situ hybridization using a ${ }^{35} \mathrm{~S}-\mathrm{UTP}$ labeled probe for $M y o D$ in regenerating murine tibialis anterior muscle four days after crush injury, from Grounds et al., 1992 [127]. Hybridisation signal (silver grains) can be observed over some mononuclear cells but not over the newly formed myotubes (arrows). Scale bar represents $25 \mu \mathrm{m}$. (B) MyoD immunolabeling of activated/proliferating satellite cells on an isolated myofibre from the flexor digitorum brevis of an adult rat after 2 days ex vivo, from Yablonka-Reuveni and Rivera, 1994 [52]. (C) Phase, DAPI nuclear counterstain and myogenin immunolabeling of a flexor digitorum brevis muscle fibre from an adult rat after 3 days ex vivo from Yablonka-Reuveni and Rivera, 1994 [52]. B and C illustrate that $\mathrm{MyoD}$ is followed by myogenin during myogenic progression in satellite cell progeny. (D) Isolated extensor digitorum longus myofibre from a $M y f 5^{\text {nlac } Z /+}$ mouse, with satellite cells localised by a blue precipitate from $\beta$-galactosidase activity from the $n l a c Z$-targeted $M y f 5$ allele following incubation in X-gal (left, arrows). DAPI counterstain (right) to visualize both satellite cell nuclei (arrows) and myonuclei, from Beauchamp et al., 2000 [15]. Images as originally published but panel labels have been amended/rearranged/added. 


\section{ASSESSING MUSCLE REGULATORY FACTOR FUNCTION USING NULL MOUSE MODELS}

Gene inactivation studies followed to understand MRF function in vivo. The first model was the $M y o D$ null mouse, which was both viable and fertile, and developed overtly normal skeletal muscle but with an increased number of satellite cells [136]. However, the satellite cells in $M y o D$-null mice were initially thought incapable of carrying out regeneration following acute (crush) injury, which was further supported by the severity of the phenotype in a chronic muscle regeneration model ( $m d x / M y o D$ null cross) [137]. Additional investigation suggested that $M y o D^{-/-}$satellite cells underwent a prolonged period of expansion (but see [138]) and differentiated poorly in vitro $[67,139,140]$, however they were subsequently shown to be able to regenerate muscle in vivo after grafting, albeit at a slower pace [141].

Genetic inactivation of the other MRFs resulted in perinatal lethality, initially precluding analysis of MRF function in adult mice. Myf5-null mice died at birth due to rib cage abnormalities, but with no obvious skeletal muscle abnormalities [142]. Myoblasts isolated at E18.5 indicated that Myf-5-null satellite cells proliferated less and differentiated precociously in vitro [138]. When Myf5-null alleles were later made that allowed survival to adult, it was found that lack of Myf5 mildly affected satellite cell function [143, 144]. However, double Myf5/MyoD mutant mice had virtually no skeletal muscle [145], showing that one of either $M y o D$ or $M y f 5$ was required for skeletal muscle formation.

Parallel studies generated two myogenin-null mouse models, both of which had severe skeletal muscle defects and died perinatally [146, 147]. Myogenesis varied regionally, with muscle tissue containing disorganized myofibres and/or high quantities of mononucleated cells. Thus, myogenin was not necessary for myogenic specification, but played a pivotal role in muscle differentiation during development that could not be substituted by other MRFs. That being said, conditional inactivation of myogenin following embryonic muscle development showed that myogenin was dispensable for subsequent muscle growth, and so for satellite cell differentiation [148].

The situation with MRF4 was more complicated, with three different groups generating MRF4 knockout mice; one of which was viable [149] while the other two died at birth $[150,151]$. However, all three had varying reductions in Myf 5 expression and resembled the Myf5-null models in terms of rib cage deformities. Since the MRF4 and Myf5 genes are close together on murine chromosome 10, it was speculated that the differences in phenotype were related to the degree to which targeting MRF4 affected the Myf5 locus in each model [152]. The viable MRF4null model had apparently normal musculature in the adult [149] but any subtle effects on satellite cell homeostasis or muscle regeneration remain unknown [10].

These early knockout studies provided fundamental insight into myogenesis that also informed on the role of the MRFs in satellite cells. MRF function in adult has recently been comprehensively reviewed [10].

\section{GENETIC MODIFICATION PROVIDES LINEAGE MARKERS FOR SATELLITE CELLS}

An extremely helpful innovation by Shahragim Tajbakhsh in the Buckingham lab was to inactivate Myf5 by inserting a nlacZ reporter gene into the $M y f 5$ locus to generate the Myf5 $5^{\text {nlac } Z}$ allele [13]. This model was especially important in absence of useful Myf5 antibodies at the time, and allowed detailed examination of $M y f 5$ expression and cell fate during development, as well as of the effects of loss of Myf5 function in null Myf $5^{\text {nlacZ } / \text { nlac Z }}$ mice [13]. Importantly, Myf5 $5^{\text {nlacZ } /+}$ mice were viable, allowing high-resolution examination of $M y f 5$ expression dynamics. Analysing Myf5 using the targeted Myf $5^{\text {nlac } Z}$ allele, combined with immunolabelling for MyoD, during muscle regeneration in vivo permitted cellular resolution. This showed eventual co-expression of the two genes in most activated satellite cells and their myoblast progeny [153]. What came as somewhat of a surprise at the time though, was that the $M y f 5^{\text {nlac } Z}$ allele also revealed Myf5 expression in quiescent satellite cells in uninjured muscle [15] (Fig. 3D). This provided an easy highthroughput/high-resolution means to detect satellite cells in any mouse muscle [15].

Also in the Buckingham lab in Paris, a series of transgenes driving nlac $Z$ had been generated in the mid 1990s by Robert Kelly to examine regulation of the sarcomeric $M L C 1 / 3 F$ gene [14, 154, 155]. Of these, the 3F-nlacZ-E transgene was robustly expressed in myonuclei [14] and so could also be used 
to identify satellite cells by their lack of transgene expression on isolated myofibres [15].

Importantly, it was realized that the 3F-nlacZ-E transgene could provide a sensitive lineage marker to determine if implanted cells contributed to host skeletal muscle [16, 156], while the $M y f 5^{\text {nlac } Z}$ allele could report contribution to the host satellite cell pool $[16,157]$.

\section{GRAFTING STUDIES DEFINE SATELLITE CELL FUNCTION}

Grafting has always been an important tool to examine muscle function, following its initial use by Volkmann in 1893 [5, 158]. Neerunjun and Dubowitz [159] and Snow [160, 161] dosed rodents with tritiated thymidine before transplanting muscles, showing that proliferating cells in regenerated muscles gave rise to labeled myonuclei. That these regenerative cells were myoblasts was confirmed by Lipton and Schultz, who labeled myoblast cultures with tritiated thymidine in vitro before grafting and detected label in myonuclei within host myofibres, but not in fibrogenic, endothelial or other non-muscle cell types [162]. Implantation of myoblasts under the skin also gave rise to myotubes [162].

Lineage tracing with tritiated thymidine however, had a number of drawbacks, including label dilution and laborious and indirect detection [122]. Having a traceable donor cell marker that was inherited only in donor-derived progeny was an obvious advantage, such as using the $\mathrm{Y}$ chromosome in male donor cells in female hosts e.g. [163]. Another strategy was grafting quail cells into chick embryos, which could then be identified in the host by virtue of their nuclear morphology [164]. This was the technique used by the Kieny group to show that satellite cells in the body, like their associated muscle fibres, originate from the somites [121].

An approach for mammalian systems employed by the Sloper group (including one Terence Partridge) used grafts between two strains of inbred mice, each homozygous for different allelic forms of the enzyme glucose-6-phosphate isomerase. This technique was used to show that donor cells could fuse with host cells or myofibres in adult muscle $[165,166]$.

Significantly, lineage tracing using isoenzymes also showed that after fusion, donor myogenic cells could introduce genes into the host muscle fibre. This led to the idea that functional versions of defective genes could also be delivered via cell fusion and would subsequently generate functional protein in genetically mosaic myofibres to treat inherited muscle disorders [167]. An appropriate model of a primary genetic muscular dystrophy was needed to test cell therapy in vivo $[168,169]$. Such a model proved to be the $m d x$ mouse that exhibited characteristics of muscular dystrophy [170]. When mutations in dystrophin were demonstrated to cause Duchenne muscular dystrophy [171], this led to identification of a nonsense mutation in exon 23 of the Dmd gene in $m d x$ mice [172]. Partridge and colleagues showed that implantation of healthy myoblasts with a functional Dmd gene could confer dystrophin expression in host $m d x$ muscle fibres [173]. There rapidly followed a series of cell therapy trials in boys with Duchene muscular dystrophy that highlighted highly challenging technical issues [169, 174]. $M d x$ mice had a comparatively mild dystrophic phenotype but a single dose of X-irradiation (16 Gy) to one leg inhibited regeneration to provide a more faithful dystrophic model and better recipient for grafting studies [175].

Grafted myoblasts could clearly form muscle and also fuse into existing muscle fibres, but a subpopulation of donor cells with stem cell-like characteristics could also be detected [176]. Labeling primary myoblasts with a retrovirus encoding nlac $Z$ before grafting, Yao and Kurachi demonstrated that a small proportion of donor-derived cells persisted as myoblasts, which could then be recovered from host tissue and would differentiate ex vivo [177]. Crucially, recovered donor cells could also form muscle when re-implanted [177]. Use of H-2Kb-tsA58 myoblast clones showed that donor myoblasts could also participate in multiple rounds of host muscle regeneration [178], thus implanted myoblasts could reenter a quiescent, stem cell-like state, but remained capable of myogenesis. Importantly, labeled myogenic clones [179] and primary myoblasts from $M y f 5^{\text {nlac } Z /+}$ mice [157] were able to occupy the satellite cell niche following grafting. Later, transplantation of single muscle fibres from $M y f 5^{\text {nlac } Z /+}$ mice led to the demonstration that satellite cells were bona fide stem cells [16], with subsequent grafting studies confirming the classification $[17,18,180]$. Interestingly satellite cells grafted when still near quiescence had better regenerative capacity $[16,180]$.

\section{SATELLITE CELLS AS STEM CELLS}

Much progress towards understanding how the satellite cell pool is maintained, as well as how such 
a small number of cells can replace large amounts of tissue so quickly, was also made during this era. The suggestion of asymmetric cell division had been made by Moss and Leblond in 1971, who proposed that half the satellite cell progeny fuse to the growing muscle fibres in 14-16 day old rats, while the other half divides again, before half of that generation again either differentiate or continue to divide, and so on [80]. This notion was reinforced by Quinn, Holtzer and Nameroff in the 1980s, who modelled myogenic cell commitment in vitro by quantifying clonal expansion of myogenic chick cells from 14 day embryos. In a series of papers, it was proposed that early myogenic precursor cells can divide either symmetrically into two stem-like progeny, or asymmetrically to produce one stem-like daughter cell that will continue to divide and one committed daughter cell that will divide a finite number of times (4) before differentiation, termed 'quantal mitosis'. These observations suggested existence of a self-renewing stem cell in the skeletal muscle lineage [181-183]. Work on mouse and chicken muscle regeneration in vivo by Grounds and McGeachie supported the observation that some cells differentiated after only a few divisions while others underwent extended proliferation, but challenged the concept of quantal mitosis dictating a uniform, finite number of divisions of committed cells prior to fusion [184-186].

Myoblasts isolated from regenerating and control muscles could also be divided into two populations on the basis of cell size and colony size formed ex vivo [187]. Myoblasts with stem cell-like properties were also identified in human cultures [188]. Some myoblasts were also found to express myogenin inside 8 hours of muscle injury indicating rapid differentiation, whereas most did not even divide much before 24 hours [189]. In addition, two compartments were described in growing rat muscle with respect to their rate of cell division [190].

Whether or not satellite cells contain a distinct stem cell lineage is still an active debate $[2,10,19]$.

\section{MODELING SATELLITE CELL MITOTIC QUIESCENCE}

Satellite cell morphology was noted to change as muscle matures, with fewer ribosomes and less rough endoplasmic reticulum, indicative of reduced metabolic activity [80]. Edward Schultz built on ear- lier work [5] to show that satellite cells also became mitotically quiescent in adult mice, as they did not label with tritiated thymidine even after 9 days of continuous administration [191]. Once isolated, adult satellite cells were reported to not undergo cell division before 24 hours (unlike embryonic/foetal myoblasts), again testifying to their mitotically quiescent state in healthy adult muscle [29].

Keeping satellite cells fully quiescent during isolation is difficult [60], so means to induce quiescence in vitro provided a useful alternative. When human primary satellite cells or $\mathrm{C} 2 \mathrm{C} 12$ cells are induced to differentiate in vitro, most form multinucleated myotubes, but a proportion of cells were observed to escape immediate differentiation to become 'reserve cells': a slowly dividing or quiescent myogenic population. Upon stimulation, reserve cells would again divide rapidly and generate either differentiationcompetent progeny, or further reserve cells $[188$, 192]. Significantly, reserve cells expressed markers characteristic of quiescent satellite cells such Myf5 and CD34 [15, 132, 133, 192]. Culture of satellite cells on isolated myofibres also demonstrated cells that returned to a quiescent state [193, 194]. Such models remain useful to explore myogenic quiescence and self-renewal.

\section{SATELLITE CELL HETEROGENEITY}

Studies on satellite cell proliferation and differentiation had indicated differences in cell behaviour, which prompted the question of whether satellite cells were a heterogeneous population. Certainly satellite cells from muscles with distinct embryonic origins were found to exhibit differences, such as expression of a cat jaw-specific superfast MyHC isoform in regenerated cat limb muscle only with prior grafting of jaw muscle-derived myogenic precursors $[195,196]$. Similarly, proliferation of myogenic cells from the first branchial-arch derived masseter was poor compared to the tibialis anterior of the limb, and masseter (although not the non-somitic-origin digastric and sternocleidomastoid) also regenerated less effectively than tibialis anterior [197]. Heterogeneity in behaviour was also noted in satellite cells from within the same muscle, with the MyHC isoform repertoire upon differentiation reported to correlate with the phenotype of their associated myofibre in mouse [58] or muscle in chicken/quail [198]. 


\section{SINGLE CELL TRANSCRIPTOMICS THE HARD WAY}

Related to heterogeneity, in a pioneering study Cornelison and Wold examined gene expression in satellite cells at the single cell level [92]. Satellite cells were identified by first treating muscle fibres with Marcaine, a myotoxic drug that kills myofibres but spares satellite cells, and then collected from their niche following a live/dead stain. RNA was extracted from individual satellite cells at various time points post-isolation, and expression levels of $C$-Met, $M$ cadherin and the four MRFs assayed using multiplex single cell RT-PCR. C-Met was expressed in all quiescent satellite cells, while $M$-cadherin was only expressed in a fraction of quiescent satellite cells, with rare MRF expression detected. Following activation, satellite cells began to express either $M y o D$ or $M y f 5$, before eventually expressing both, followed by myogenin then MRF4 [92]. A follow up single cell analysis examined satellite cells from $M y o D$-null mice [140]. While single cell technology is all the rage these days e.g. [199, 200], the Cornelison and Wold [92] study was heroic.

\section{NON-SATELLITE CELLS IN REGENERATIVE MYOGENESIS}

Satellite cell function is supported and controlled by non-muscle cells [201,202], and the 1990s saw the beginning of our understanding of how non-satellite cell types assist muscle regeneration. While invasion by neutrophils occurred first, macrophages were the main immune cells present by 2 days of muscle regeneration, with an initial population concerned with phagocytosis and clearing debris, before a later population emerged that supported muscle regeneration [203-205]. Indeed, co-culture of macrophages increased satellite cell-derived myoblasts proliferation and differentiation via secreted factors [206-208] and macrophages were found essential for muscle regeneration [209]. Further cell types supporting satellite cell function and muscle regeneration have subsequently emerged, such as fibro/adipogenic progenitors [210].

It is pertinent to note that the late 1990s also saw the claim of non-muscle cell or unorthodox sources for myogenesis. This had long been mooted, until the discovery of satellite cells seemingly defined the source of postnatal myoblasts [5]. Using the glucose-6-phosphate isomerase model,
Grounds had reconstituted the bone marrow of irradiated mice, but could not detect a donor-derived contribution to muscle regeneration using Western blot to distinguish chimeric isoenzymes [211]. However, the single cell resolution afforded by the 3F-nlacZ-E transgene allowed Mavilio, Cossu and colleagues to spot individual skeletal muscle myonuclei after direct transplantation of donor bone marrow from 3F-nlacZ-E mice into regenerating host wild-type mouse muscle [156]. Donor cell recruitment into regenerating host muscles following bone marrow transplantation into lethally-irradiated or non-irradiated host animals was also reported [156, 163].

A population of bone marrow cells could be purified due to their relative ability to exclude Hoechst dye, which was thought to include the most primitive haematopoietic stem cells; a population that was called side population or SP cells [212]. Intravenous injection of either wild-type haematopoietic stem cells or bone marrow-derived SP cells into irradiated $m d x$ mice gave reconstitution of the haematopoietic lineage, as well as donor-derived nuclei in host muscle as detected by donor-derived dystrophin expression [213]. Pericytes from the embryonic aorta and other vessels were also able to contribute to skeletal muscle upon grafting using the $3 \mathrm{~F}-$-nlacZ-E mouse [214].

Other potential unorthodox sources of muscle followed over the years [215], but modifying the Pax7 locus to genetically ablate satellite cells showed that such unorthodox cells were unable to replace satellite cell function in muscle regeneration [1]. Nevertheless, alternative sources of muscle continue to be explored for therapeutic value e.g. [216]. Techniques to direct induced pluripotent stem cells [217] towards the skeletal myogenic and satellite cell lineages [218] certainly fall under the 'non-muscle or unorthodox sources for muscle' moniker.

\section{SATELLITE CELL MEETINGS}

Arguably, another foundation in satellite cell research initiated last century was establishment of the FASEB Satellite Cell Meetings! In 1969, the Muscular Dystrophy Associations of America Inc sponsored the first international conference on muscle regeneration, chaired by Alexander Mauro at the Institute for Muscle Disease in New York. The proceedings of the meeting were published the following year in a book titled 'Regeneration of Skeletal Muscle 
Imaging of satellite cells on isolated muscle fibres to assess their number/distribution [50]

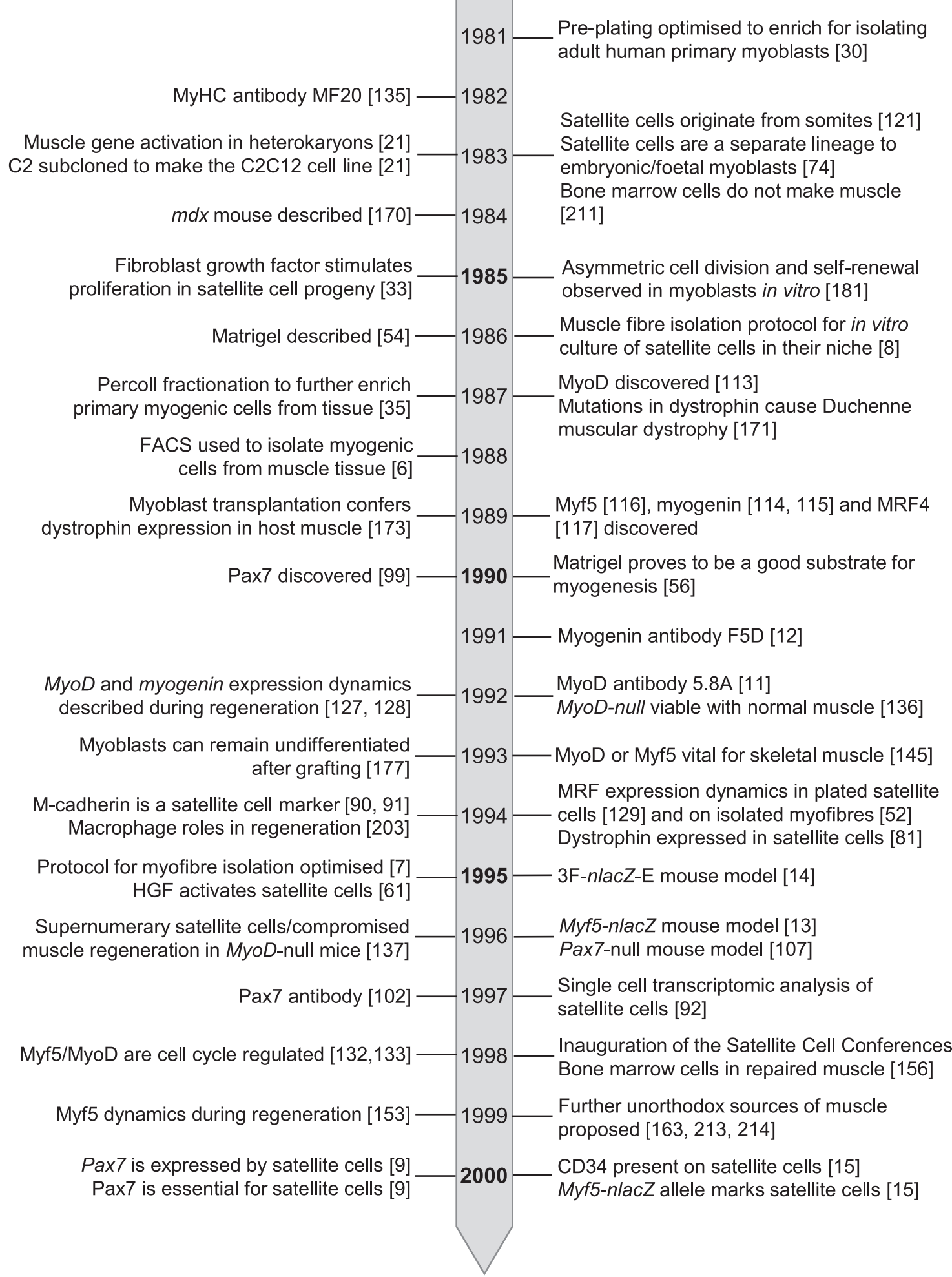

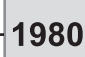
Bone marrow cells do not make muscle Asymmetric cell division and self-renewal observed in myoblasts in vitro [181]

Percoll fractionation to further enrich

FACS used to isolate myogenic ells from muscle tissue [6]

Myoblast transplantation confers Pax7 discovered [99]

Fig. 4. Timeline of seminal events in satellite cell research from $1980-2000$. 
and Myogenesis', edited by Alexander Mauro, Saiyid Shafiq and Ade Mihorat [219]. This was followed in 1978 by a second conference on muscle regeneration at the Rockefeller University in New York, with the papers again collated in book form edited by Alexander Mauro in 1979, and simply called 'Muscle Regeneration' [220]. Mauro's final contribution to the satellite story was his 1988 paper reporting no tight electrical coupling between satellite cells and their associated muscle fibre [221], before his death in October 1989 (his obituary in the New York Times mentions him as co-inventor of one of the first cardiac pacemakers, but no mention of satellite cells!). Satellite cells also featured in the Muscular Dystrophy Association International Conference on Myoblast Transfer Therapy in 1989, again in New York [222].

Satellite cell research did not really feature prominently in Myogenesis meetings of the 1990s, which were dominated by research focused around muscle development. This prompted a push for a conference again dedicated to satellite cells and postnatal myogenesis, and a steering committee of Judy Anderson, Ron Allen, Steve Hauschka, Orna Halevy, Miranda Grounds, Gillian Butler-Browne, Anna StarzinskiPowitz and Zipora Yablonka-Reuveni formed during the 1997 'Molecular Biology of Muscle Development' Keystone meeting. Judy Anderson and Ron Allen then largely organized and co-chaired that first meeting called 'Post-natal Myogenesis: Satellite Cells in Action!' in August 1998 in Boston, USA, which also instigated the 'The Alexander Mauro Lecture', first given by Richard Bischoff (the program and announcements are included here as supplementary information). The subsequent nine meetings, starting in 2001, have been organized under the auspices of FASEB and remain a central platform for the skeletal muscle and satellite cell community.

\section{SUMMARY}

By the turn of the century then, the foundations in knowledge, tools and technology had been laid [5] (Fig. 4) to support satellite cell research in the 21 st century. While the depth and nuance of our understanding of satellite cell function and muscle regeneration has greatly advanced in recent years [2, 19], these studies remain central pillars of regenerative myogenesis.

\section{ACKNOWLEDGMENTS}

This review is dedicated to the boundlessly inquisitive and enthusiastic Terence A. Partridge on the occasion of his 80th Birthday. Thanks to Zipora Yablonka-Reuveni and Judy Anderson for valuable feedback and to Dawn Cornelison for finding the autographed 1998 program. Elise Engquist is supported by Wellcome Trust 222352/Z/21/Z from $108874 / \mathrm{B} / 15 / \mathrm{Z}$. The Zammit lab is supported by grants from the Medical Research Council to P.S.Z. (MR/P023215/1 and MR/S002472/1), from Muscular Dystrophy UK (RA3/3052), Association Française contre les Myopathies (AFM 17865) and the FSH Society (FSHS-82013-06 and FSHS82017-05). Images are reproduced from published papers as indicated and with permission: Figure 1A - License Number 5057590765121, Fig. 1B - License Number 5057610080932, Fig. 1C License Number 5057611172253 (at a cost of $£ 75.65$ - thanks Springer-Nature), Fig. 2A - License Number 5045410222306, Fig. 2B - License Number 5045410473405, Fig. 2C and 2D - License Number 5045410713875, Fig. 2E and F - Order license ID 1113708-1, Fig. 3A - License Number 5058860350012 (with another $£ 75.65$ to SpringerNature!) and Fig. 3B and C - License Number 5052430512923.

\section{CONFLICT OF INTEREST}

The authors declare that there are no conflicts of interest.

\section{SUPPLEMENTARY MATERIAL}

The supplementary material is available in the electronic version of this article: https://dx.doi.org/ 10.3233/JND-210705.

\section{REFERENCES}

[1] Relaix F, Zammit PS. Satellite cells are essential for skeletal muscle regeneration: The cell on the edge returns centre stage. Development. 2012;139:2845-56.

[2] Forcina L, Miano C, Pelosi L, Musaro A. An Overview about the Biology of Skeletal Muscle Satellite Cells. Current Genomics. 2019;20:24-37.

[3] Mauro A. Satellite cell of skeletal muscle fibers. J Biophys Biochem Cytol. 1961;9:493-5.

[4] Katz B. The terminations of the afferent nerve fibre in the muscle spindle of the frog. Philos Trans R Soc Lond (Biol). 1961;243:221-40. 
[5] Scharner J, Zammit PS. The muscle satellite cell at 50: The formative years. Skelet Muscle. 2011;1:28.

[6] Webster C, Pavlath GK, Parks DR, Walsh FS, Blau HM. Isolation of human myoblasts with the fluorescenceactivated cell sorter. Exp Cell Res. 1988;174:252-65.

[7] Rosenblatt JD, Lunt AI, Parry DJ, Partridge TA. Culturing satellite cells from living single muscle fiber explants. In Vitro Cell Dev Biol Anim. 1995;31:773-9.

[8] Bischoff R. Proliferation of muscle satellite cells on intact myofibers in culture. Dev Biol. 1986;115:129-39.

[9] Seale P, Sabourin LA, Girgis-Gabardo A, Mansouri A, Gruss P, Rudnicki MA. Pax7 is required for the specification of myogenic satellite cells. Cell. 2000;102:777-86.

[10] Zammit PS. Function of the myogenic regulatory factors Myf5, MyoD, Myogenin and MRF4 in skeletal muscle, satellite cells and regenerative myogenesis. Semin Cell Dev Biol. 2017;72:19-32.

[11] Dias P, Parham DM, Shapiro DN, Tapscott SJ, Houghton PJ. Monoclonal antibodies to the myogenic regulatory protein MyoD1: Epitope mapping and diagnostic utility. Cancer Res. 1992;52:6431-9.

[12] Wright WE, Binder M, Funk W. Cyclic amplification and selection of targets (CASTing) for the myogenin consensus binding site. Mol Cell Biol. 1991;11:4104-10.

[13] Tajbakhsh S, Rocancourt D, Buckingham M. Muscle progenitor cells failing to respond to positional cues adopt non-myogenic fates in myf-5 null mice. Nature. 1996;384:266-70.

[14] Kelly R, Alonso S, Tajbakhsh S, Cossu G, Buckingham M. Myosin light chain 3F regulatory sequences confer regionalized cardiac and skeletal muscle expression in transgenic mice. J Cell Biol. 1995;129:383-96.

[15] Beauchamp JR, Heslop L, Yu DS, et al. Expression of CD34 and Myf5 defines the majority of quiescent adult skeletal muscle satellite cells. J Cell Biol. 2000;151:122134.

[16] Collins CA, Olsen I, Zammit PS, et al. Stem cell function, self-renewal, and behavioral heterogeneity of cells from the adult muscle satellite cell niche. Cell. 2005;122:289301.

[17] Sacco A, Doyonnas R, Kraft P, Vitorovic S, Blau HM. Self-renewal and expansion of single transplanted muscle stem cells. Nature. 2008;456:502-6.

[18] Rocheteau P, Gayraud-Morel B, Siegl-Cachedenier I, Blasco MA, Tajbakhsh S. A subpopulation of adult skeletal muscle stem cells retains all template DNA strands after cell division. Cell. 2012;148:112-25.

[19] Relaix F, Bencze M, Borok MJ, et al. Perspectives on skeletal muscle stem cells. Nature communications. 2021;12:692.

[20] Yaffe D, Saxel O. Serial passaging and differentiation of myogenic cells isolated from dystrophic mouse muscle. Nature. 1977;270:725-7.

[21] Blau HM, Chiu CP, Webster C. Cytoplasmic activation of human nuclear genes in stable heterocaryons. Cell. 1983;32:1171-80.

[22] Hauschka SD, Linkhart TA, Clegg C, Merrill G. Clonal Studies of Human and Mouse Muscle In: Mauro A ed. Muscle Regeneration. New York: Raven Press. 1979:31122.

[23] Linkhart TA, Clegg CH, Hauschika SD. Myogenic differentiation in permanent clonal mouse myoblast cell lines: Regulation by macromolecular growth factors in the culture medium. Dev Biol. 1981;86:19-30.
[24] Morgan JE, Beauchamp JR, Pagel CN, et al. Myogenic cell lines derived from transgenic mice carrying a thermolabile T antigen: A model system for the derivation of tissue-specific and mutation-specific cell lines. Dev Biol. 1994;162:486-98.

[25] Mamchaoui K, Trollet C, Bigot A, et al. Immortalized pathological human myoblasts: Towards a universal tool for the study of neuromuscular disorders. Skelet Muscle. 2011;1:34.

[26] Krom YD, Dumonceaux J, Mamchaoui K, et al. Generation of isogenic D4Z4 contracted and noncontracted immortal muscle cell clones from a mosaic patient: A cellular model for FSHD. Am J Pathol. 2012;181:1387-401.

[27] Florini JR, Magri KA. Effects of growth factors on myogenic differentiation. Am J Physiol. 1989;256:C701-11.

[28] Bischoff R. Enzymatic liberation of myogenic cells from adult rat muscle. Anat Rec. 1974;180:645-61.

[29] Bischoff R. Tissue Culture Studies on the Origin of Myogenic Cells During Muscle Regeneration in the Rat. In: Mauro A ed. Muscle Regeneration. New York: Raven Press. 1979:13-29.

[30] Blau HM, Webster C. Isolation and characterization of human muscle cells. Proc Natl Acad Sci U S A. 1981;78:5623-7.

[31] Blau HM, Webster C, Chiu CP, Guttman S, Chandler F. Differentiation properties of pure populations of human dystrophic muscle cells. Exp Cell Res. 1983;144:495-503.

[32] Kim KH, Qiu J, Kuang S. Isolation, Culture, and Differentiation of Primary Myoblasts Derived from Muscle Satellite Cells. Bio Protoc. 2020;10:e3686.

[33] Allen RE, Dodson MV, Luiten LS. Regulation of skeletal muscle satellite cell proliferation by bovine pituitary fibroblast growth factor. Exp Cell Res. 1984;152: 154-60.

[34] Allen RE, Dodson MV, Luiten LS, Boxhorn LK. A serumfree medium that supports the growth of cultured skeletal muscle satellite cells. In Vitro Cell Dev Biol. 1985;21:63640.

[35] Yablonka-Reuveni Z, Quinn LS, Nameroff M. Isolation and clonal analysis of satellite cells from chicken pectoralis muscle. Dev Biol. 1987;119:252-9.

[36] Morgan JE. Myogenicity in vitro and in vivo of mouse muscle cells separated on discontinuous Percoll gradients. J Neurol Sci. 1988;85:197-207.

[37] Yablonka-Reuveni Z, Nameroff M. Temporal differences in desmin expression between myoblasts from embryonic and adult chicken skeletal muscle. Differentiation. 1990;45:21-8.

[38] Liu L, Cheung TH, Charville GW, Rando TA. Isolation of skeletal muscle stem cells by fluorescence-activated cell sorting. Nat Protoc. 2015;10:1612-24.

[39] Bosnakovski D, Xu Z, Li W, et al. Prospective isolation of skeletal muscle stem cells with a Pax7 reporter. Stem Cells. 2008;26:3194-204.

[40] Agley CC, Rowlerson AM, Velloso CP, Lazarus NL, Harridge $\mathrm{SD}$. Isolation and quantitative immunocytochemical characterization of primary myogenic cells and fibroblasts from human skeletal muscle. J Vis Exp. 2015:52049.

[41] Konigsberg UR, Lipton BH, Konigsberg IR. The regenerative response of single mature muscle fibers isolated in vitro. Dev Biol. 1975;45:260-75.

[42] Konigsberg IR. Regeneration of Single Muscle Fibres in Culture and In Vivo. In: Mauro A ed. Muscle regeneration. New York: Raven Press. 1979:281-4. 
[43] Bischoff R. Regeneration of single skeletal muscle fibers in vitro. Anat Rec. 1975;182:215-35.

[44] Webster MT, Manor U, Lippincott-Schwartz J, Fan CM. Intravital Imaging Reveals Ghost Fibers as Architectural Units Guiding Myogenic Progenitors during Regeneration. Cell Stem Cell. 2016;18:243-52.

[45] Kopriwa BM, Moss FP. A radioautographic technique for whole mounts of muscle fibers. J Histochem Cytochem. 1971;19:51-5.

[46] Betz W, Sakmann B. Effects of proteolytic enzymes on function and structure of frog neuromuscular junctions. J Physiol. 1973;230:673-88.

[47] Bekoff A, Betz W. Properties of isolated adult rat muscle fibres maintained in tissue culture. J Physiol. 1977;271:537-47.

[48] Rubin LL, Keller CE, Schuetze SM. Satellite Cells in Isolated Adult Muscle Fibres in Tissue Culture. In: Mauro A ed. Muscle Regeneration. New York: Raven Press. 1979:281-4.

[49] Lawrence T, Mauro A. Identification of Satelite Cells In Vitro in Frog Muscle Fibers by Nomarski Optics. In: Mauro A ed. Muscle Regeneration. New York: Raven Press. 1979:275-80.

[50] Cull-Candy SG, Miledi R, Nakajima Y, Uchitel OD. Visualization of satellite cells in living muscle fibres of the frog. Proc R Soc Lond B Biol Sci. 1980;209:563-8.

[51] Bischoff R. A satellite cell mitogen from crushed adult muscle. Dev Biol. 1986;115:140-7.

[52] Yablonka-Reuveni Z, Rivera AJ. Temporal expression of regulatory and structural muscle proteins during myogenesis of satellite cells on isolated adult rat fibers. Dev Biol. 1994;164:588-603.

[53] Yablonka-Reuveni Z, Seger R, Rivera AJ. Fibroblast growth factor promotes recruitment of skeletal muscle satellite cells in young and old rats. J Histochem Cytochem. 1999;47:23-42.

[54] Kleinman HK, McGarvey ML, Hassell JR, et al. Basement membrane complexes with biological activity. Biochemistry. 1986;25:312-8.

[55] Kleinman HK, Martin GR. Matrigel: Basement membrane matrix with biological activity. Semin Cancer Biol. 2005;15:378-86.

[56] Hartley RS, Yablonka-Reuveni Z. Long-term maintenance of primary myogenic cultures on a reconstituted basement membrane. In Vitro Cell Dev Biol. 1990;26:955-61.

[57] Lazarides E, Hubbard BD. Immunological characterization of the subunit of the 100 A filaments from muscle cells. Proc Natl Acad Sci U S A. 1976;73:4344-8.

[58] Rosenblatt JD, Parry DJ, Partridge TA. Phenotype of adult mouse muscle myoblasts reflects their fiber type of origin. Differentiation. 1996;60:39-45.

[59] Anderson JE, Wozniak AC, Mizunoya W. Single musclefiber isolation and culture for cellular, molecular, pharmacological, and evolutionary studies. Methods Mol Biol. 2012;798:85-102.

[60] Machado L, Esteves de Lima J, Fabre O, et al. In Situ Fixation Redefines Quiescence and Early Activation of Skeletal Muscle Stem Cells. Cell Reports. 2017;21:198293.

[61] Allen RE, Sheehan SM, Taylor RG, Kendall TL, Rice GM. Hepatocyte growth factor activates quiescent skeletal muscle satellite cells in vitro. J Cell Physiol. 1995;165: 307-12.

[62] Tatsumi R, Anderson JE, Nevoret CJ, Halevy O, Allen RE. HGF/SF is present in normal adult skeletal mus- cle and is capable of activating satellite cells. Dev Biol. 1998;194:114-28.

[63] Anderson JE. A role for nitric oxide in muscle repair: Nitric oxide-mediated activation of muscle satellite cells. Mol Biol Cell. 2000;11:1859-74.

[64] Wozniak AC, Pilipowicz O, Yablonka-Reuveni Z, et al. $\mathrm{C}$-Met expression and mechanical activation of satellite cells on cultured muscle fibers. J Histochem Cytochem. 2003;51:1437-45.

[65] Collins CA, Zammit PS, Ruiz AP, Morgan JE, Partridge TA. A population of myogenic stem cells that survives skeletal muscle aging. Stem Cells. 2007;25:885-94.

[66] Bockhold KJ, Rosenblatt JD, Partridge TA. Aging normal and dystrophic mouse muscle: Analysis of myogenicity in cultures of living single fibers. Muscle Nerve. 1998;21:173-83.

[67] Yablonka-Reuveni Z, Rudnicki MA, Rivera AJ, Primig M, Anderson JE, Natanson P. The transition from proliferation to differentiation is delayed in satellite cells from mice lacking MyoD. Dev Biol. 1999;210:440-55.

[68] Moyle LA, Zammit PS. Isolation, culture and immunostaining of skeletal muscle fibres to study myogenic progression in satellite cells. Methods Mol Biol. 2014;1210:63-78.

[69] Huttner SS, Hayn C, Ahrens HE, Schmidt M, Henze H, von Maltzahn J. Single Myofiber Culture Assay for the Assessment of Adult Muscle Stem Cell Functionality Ex Vivo. J Vis Exp. 2021.

[70] Ganassi M, Badodi S, Wanders K, Zammit PS, Hughes $\mathrm{SM}$. Myogenin is an essential regulator of adult myofibre growth and muscle stem cell homeostasis. eLife. 2020;9.

[71] Cardasis CA, Cooper GW. An analysis of nuclear numbers in individual muscle fibers during differentiation and growth: A satellite cell-muscle fiber growth unit. J Exp Zool. 1975;191:347-58.

[72] Ontell M, Kozeka K. The organogenesis of murine striated muscle: A cytoarchitectural study. Am J Anat. 1984;171:133-48.

[73] Bonner PH, Hauschka SD. Clonal analysis of vertebrate myogenesis. I. Early developmental events in the chick limb. Dev Biol. 1974;37:317-28.

[74] Cossu G, Molinaro M, Pacifici M. Differential response of satellite cells and embryonic myoblasts to a tumor promoter. Dev Biol. 1983;98:520-4.

[75] Senni MI, Castrignano F, Poiana G, Cossu G, Scarsella G, Biagioni S. Expression of adult fast pattern of acetylcholinesterase molecular forms by mouse satellite cells in culture. Differentiation. 1987;36:194-8.

[76] Hartley RS, Bandman E, Yablonka-Reuveni Z. Skeletal muscle satellite cells appear during late chicken embryogenesis. Dev Biol. 1992;153:206-16.

[77] Feldman JL, Stockdale FE. Temporal appearance of satellite cells during myogenesis. Dev Biol. 1992;153:21726.

[78] Hartley RS, Bandman E, Yablonka-Reuveni Z. Myoblasts from fetal and adult skeletal muscle regulate myosin expression differently. Dev Biol. 1991;148:249-60.

[79] Johnson SE, Allen RE. Proliferating cell nuclear antigen (PCNA) is expressed in activated rat skeletal muscle satellite cells. J Cell Physiol. 1993;154:39-43.

[80] Moss FP, Leblond CP. Satellite cells as the source of nuclei in muscles of growing rats. Anat Rec. 1971;170:421-35.

[81] Zhang M, McLennan IS. Use of antibodies to identify satellite cells with a light microscope. Muscle Nerve. 1994;17:987-94. 
[82] Dumont NA, Wang YX, von Maltzahn J, et al. Dystrophin expression in muscle stem cells regulates their polarity and asymmetric division. Nat Med. 2015;21:1455-63.

[83] Schubert W, Zimmermann K, Cramer M, StarzinskiPowitz A. Lymphocyte antigen Leu-19 as a molecular marker of regeneration in human skeletal muscle. Proc Natl Acad Sci U S A. 1989;86:307-11.

[84] Lanier LL, Testi R, Bindl J, Phillips JH. Identity of Leu-19 (CD56) leukocyte differentiation antigen and neural cell adhesion molecule. J Exp Med. 1989;169:2233-8.

[85] Covault J, Sanes JR. Distribution of N-CAM in synaptic and extrasynaptic portions of developing and adult skeletal muscle. J Cell Biol. 1986;102:716-30.

[86] Illa I, Leon-Monzon M, Dalakas MC. Regenerating and denervated human muscle fibers and satellite cells express neural cell adhesion molecule recognized by monoclonal antibodies to natural killer cells. Ann Neurol. 1992;31:4652.

[87] Dubois C, Figarella-Branger D, Pastoret C, Rampini C, Karpati G, Rougon G. Expression of NCAM and its polysialylated isoforms during $\mathrm{mdx}$ mouse muscle regeneration and in vitro myogenesis. Neuromuscul Disord. 1994;4:171-82.

[88] Donalies M, Cramer M, Ringwald M, Starzinski-Powitz A. Expression of M-cadherin, a member of the cadherin multigene family, correlates with differentiation of skeletal muscle cells. Proc Natl Acad Sci U S A. 1991;88:8024-8.

[89] Moore R, Walsh FS. The cell adhesion molecule Mcadherin is specifically expressed in developing and regenerating, but not denervated skeletal muscle. Development. 1993;117:1409-20.

[90] Irintchev A, Zeschnigk M, Starzinski-Powitz A, Wernig A. Expression pattern of M-cadherin in normal, denervated, and regenerating mouse muscles. Dev Dyn. 1994;199:32637.

[91] Bornemann A, Schmalbruch H. Immunocytochemistry of $\mathrm{M}$-cadherin in mature and regenerating rat muscle. Anat Rec. 1994;239:119-25.

[92] Cornelison DD, Wold BJ. Single-cell analysis of regulatory gene expression in quiescent and activated mouse skeletal muscle satellite cells. Dev Biol. 1997;191:270-83.

[93] Gal-Levi R, Leshem Y, Aoki S, Nakamura T, Halevy O. Hepatocyte growth factor plays a dual role in regulating skeletal muscle satellite cell proliferation and differentiation. Biochim Biophys Acta. 1998;1402:39-51.

[94] Kastner S, Elias MC, Rivera AJ, Yablonka-Reuveni Z. Gene expression patterns of the fibroblast growth factors and their receptors during myogenesis of rat satellite cells. J Histochem Cytochem. 2000;48:1079-96.

[95] Garry DJ, Yang Q, Bassel-Duby R, Williams RS. Persistent expression of MNF identifies myogenic stem cells in postnatal muscles. Dev Biol. 1997;188:280-94.

[96] Garry DJ, Meeson A, Elterman J, et al. Myogenic stem cell function is impaired in mice lacking the forkhead/winged helix protein MNF. Proc Natl Acad Sci U S A. 2000;97:5416-21.

[97] Zammit P, Beauchamp J. The skeletal muscle satellite cell: Stem cell or son of stem cell? Differentiation. 2001;68:193-204.

[98] Boldrin L, Morgan JE. Human satellite cells: Identification on human muscle fibres. PLoS Curr. 2012;3:RRN1294.

[99] Jostes B, Walther C, Gruss P. The murine paired box gene, Pax7, is expressed specifically during the development of the nervous and muscular system. Mech Dev. 1990;33:2737.
[100] Goulding MD, Chalepakis G, Deutsch U, Erselius JR, Gruss P. Pax-3, a novel murine DNA binding protein expressed during early neurogenesis. EMBO J. 1991;10:1135-47.

[101] Seale P, Ishibashi J, Holterman C, Rudnicki MA. Muscle satellite cell-specific genes identified by genetic profiling of MyoD-deficient myogenic cell. Dev Biol. 2004;275:287-300.

[102] Kawakami A, Kimura-Kawakami M, Nomura T, Fujisawa H. Distributions of PAX6 and PAX7 proteins suggest their involvement in both early and late phases of chick brain development. Mech Dev. 1997;66:119-30.

[103] Morrison JI, Loof S, He P, Simon A. Salamander limb regeneration involves the activation of a multipotent skeletal muscle satellite cell population. J Cell Biol. 2006;172:433-40.

[104] Halevy O, Piestun Y, Allouh MZ, et al. Pattern of Pax7 expression during myogenesis in the posthatch chicken establishes a model for satellite cell differentiation and renewal. Dev Dyn. 2004;231:489-502.

[105] Reimann J, Brimah K, Schroder R, Wernig A, Beauchamp JR, Partridge TA. Pax7 distribution in human skeletal muscle biopsies and myogenic tissue cultures. Cell Tissue Res. 2004;315:233-42.

[106] Marg A, Escobar H, Gloy S, et al. Human satellite cells have regenerative capacity and are genetically manipulable. J Clin Invest. 2014;124:4257-65.

[107] Mansouri A, Stoykova A, Torres M, Gruss P. Dysgenesis of cephalic neural crest derivatives in Pax7-/- mutant mice. Development. 1996;122:831-8.

[108] Murphy MM, Lawson JA, Mathew SJ, Hutcheson DA, Kardon G. Satellite cells, connective tissue fibroblasts and their interactions are crucial for muscle regeneration. Development. 2011;138:3625-37.

[109] Taylor SM, Jones PA. Multiple new phenotypes induced in 10T1/2 and $3 \mathrm{~T} 3$ cells treated with 5-azacytidine. Cell. 1979;17:771-9.

[110] Jones PA, Taylor SM. Cellular differentiation, cytidine analogs and DNA methylation. Cell. 1980;20:85-93.

[111] Konieczny SF, Emerson CP, Jr. 5-Azacytidine induction of stable mesodermal stem cell lineages from 10T1/2 cells: Evidence for regulatory genes controlling determination. Cell. 1984;38:791-800.

[112] Lassar AB, Paterson BM, Weintraub H. Transfection of a DNA locus that mediates the conversion of $10 \mathrm{~T} 1 / 2$ fibroblasts to myoblasts. Cell. 1986;47:649-56.

[113] Davis RL, Weintraub H, Lassar AB. Expression of a single transfected cDNA converts fibroblasts to myoblasts. Cell. 1987;51:987-1000.

[114] Wright WE, Sassoon DA, Lin VK. Myogenin, a factor regulating myogenesis, has a domain homologous to MyoD. Cell. 1989;56:607-17.

[115] Edmondson DG, Olson EN. A gene with homology to the myc similarity region of MyoD1 is expressed during myogenesis and is sufficient to activate the muscle differentiation program. Genes Dev. 1989;3:628-40.

[116] Braun T, Buschhausen-Denker G, Bober E, Tannich E, Arnold $\mathrm{HH}$. A novel human muscle factor related to but distinct from MyoD1 induces myogenic conversion in 10T1/2 fibroblasts. EMBO J. 1989;8:701-9.

[117] Rhodes SJ, Konieczny SF. Identification of MRF4: A new member of the muscle regulatory factor gene family. Genes Dev. 1989;3:2050-61.

[118] Braun T, Bober E, Winter B, Rosenthal N, Arnold HH. Myf-6, a new member of the human gene family of myo- 
genic determination factors: Evidence for a gene cluster on chromosome 12. EMBO J. 1990;9:821-31.

[119] Chal J, Pourquie O. Making muscle: Skeletal myogenesis in vivo and in vitro. Development. 2017;144:2104-22.

[120] Comai G, Tajbakhsh S. Molecular and cellular regulation of skeletal myogenesis. Curr Top Dev Biol. 2014;110:173.

[121] Armand O, Boutineau AM, Mauger A, Pautou MP, Kieny M. Origin of satellite cells in avian skeletal muscles. Arch Anat Microsc Morphol Exp. 1983;72:163-81.

[122] Sassoon D, Lyons G, Wright WE, et al. Expression of two myogenic regulatory factors myogenin and MyoD1 during mouse embryogenesis. Nature. 1989;341:303-7.

[123] Bober E, Lyons GE, Braun T, Cossu G, Buckingham M, Arnold HH. The muscle regulatory gene, Myf-6, has a biphasic pattern of expression during early mouse development. J Cell Biol. 1991;113:1255-65.

[124] Hinterberger TJ, Sassoon DA, Rhodes SJ, Konieczny SF. Expression of the muscle regulatory factor MRF4 during somite and skeletal myofiber development. Dev Biol. 1991;147:144-56.

[125] Voytik SL, Przyborski M, Badylak SF, Konieczny SF. Differential expression of muscle regulatory factor genes in normal and denervated adult rat hindlimb muscles. Dev Dyn. 1993;198:214-24.

[126] Hughes SM, Taylor JM, Tapscott SJ, Gurley CM, Carter WJ, Peterson CA. Selective accumulation of MyoD and myogenin mRNAs in fast and slow adult skeletal muscle is controlled by innervation and hormones. Development. 1993;118:1137-47.

[127] Grounds MD, Garrett KL, Lai MC, Wright WE, Beilharz MW. Identification of skeletal muscle precursor cells in vivo by use of MyoD1 and myogenin probes. Cell Tissue Res. 1992;267:99-104.

[128] Fuchtbauer EM, Westphal H. MyoD and myogenin are coexpressed in regenerating skeletal muscle of the mouse. Dev Dyn. 1992;193:34-9.

[129] Smith CK, 2nd, Janney MJ, Allen RE. Temporal expression of myogenic regulatory genes during activation, proliferation, and differentiation of rat skeletal muscle satellite cells. J Cell Physiol. 1994;159:379-85.

[130] Nicolas N, Gallien CL, Chanoine C. Analysis of MyoD, myogenin, and muscle-specific gene mRNAs in regenerating Xenopus skeletal muscle. Dev Dyn. 1996;207:60-8.

[131] Smith TH, Block NE, Rhodes SJ, Konieczny SF, Miller JB. A unique pattern of expression of the four muscle regulatory factor proteins distinguishes somitic from embryonic, fetal and newborn mouse myogenic cells. Development. 1993;117:1125-33.

[132] Lindon C, Montarras D, Pinset C. Cell cycle-regulated expression of the muscle determination factor Myf5 in proliferating myoblasts. J Cell Biol. 1998;140:111-8.

[133] Kitzmann M, Carnac G, Vandromme M, Primig M, Lamb NJ, Fernandez A. The muscle regulatory factors MyoD and myf- 5 undergo distinct cell cycle-specific expression in muscle cells. J Cell Biol. 1998;142:1447-59.

[134] Cusella-De Angelis MG, Lyons G, Sonnino C, et al. MyoD, myogenin independent differentiation of primordial myoblasts in mouse somites. J Cell Biol. 1992;116:1243-55.

[135] Bader D, Masaki T, Fischman DA. Immunochemical analysis of myosin heavy chain during avian myogenesis in vivo and in vitro. J Cell Biol. 1982;95:763-70.

[136] Rudnicki MA, Braun T, Hinuma S, Jaenisch R. Inactivation of MyoD in mice leads to up-regulation of the myogenic HLH gene Myf-5 and results in apparently normal muscle development. Cell. 1992;71:383-90.

[137] Megeney LA, Kablar B, Garrett K, Anderson JE, Rudnicki MA. MyoD is required for myogenic stem cell function in adult skeletal muscle. Genes Dev. 1996;10:1173-83.

[138] Montarras D, Lindon C, Pinset C, Domeyne P. Cultured myf5 null and myoD null muscle precursor cells display distinct growth defects. Biol Cell. 2000;92:565-72.

[139] Sabourin LA, Girgis-Gabardo A, Seale P, Asakura A, Rudnicki MA. Reduced differentiation potential of primary MyoD-/- myogenic cells derived from adult skeletal muscle. J Cell Biol. 1999;144:631-43.

[140] Cornelison DD, Olwin BB, Rudnicki MA, Wold BJ. MyoD(-/-) satellite cells in single-fiber culture are differentiation defective and MRF4 deficient. Dev Biol. 2000;224:122-37

[141] White JD, Scaffidi A, Davies M, McGeachie J, Rudnicki MA, Grounds MD. Myotube formation is delayed but not prevented in MyoD-deficient skeletal muscle: Studies in regenerating whole muscle grafts of adult mice. J Histochem Cytochem. 2000;48:1531-44.

[142] Braun T, Rudnicki MA, Arnold HH, Jaenisch R. Targeted inactivation of the muscle regulatory gene Myf-5 results in abnormal rib development and perinatal death. Cell. 1992;71:369-82.

[143] Gayraud-Morel B, Chretien F, Flamant P, Gomes D, Zammit PS, Tajbakhsh S. A role for the myogenic determination gene Myf5 in adult regenerative myogenesis. Dev Biol. 2007;312:13-28.

[144] Ustanina S, Carvajal J, Rigby P, Braun T. The myogenic factor Myf5 supports efficient skeletal muscle regeneration by enabling transient myoblast amplification. Stem Cells. 2007;25:2006-16.

[145] Rudnicki MA, Schnegelsberg PN, Stead RH, Braun T, Arnold HH, Jaenisch R. MyoD or Myf-5 is required for the formation of skeletal muscle. Cell. 1993;75: 1351-9.

[146] Nabeshima Y, Hanaoka K, Hayasaka M, et al. Myogenin gene disruption results in perinatal lethality because of severe muscle defect. Nature. 1993;364:532-5.

[147] Hasty P, Bradley A, Morris JH, et al. Muscle deficiency and neonatal death in mice with a targeted mutation in the myogenin gene. Nature. 1993;364:501-6.

[148] Knapp JR, Davie JK, Myer A, Meadows E, Olson EN, Klein WH. Loss of myogenin in postnatal life leads to normal skeletal muscle but reduced body size. Development. 2006;133:601-10.

[149] Zhang W, Behringer RR, Olson EN. Inactivation of the myogenic bHLH gene MRF4 results in up-regulation of myogenin and rib anomalies. Genes Dev. 1995;9: 1388-99.

[150] Braun T, Arnold HH. Inactivation of Myf-6 and Myf-5 genes in mice leads to alterations in skeletal muscle development. EMBO J. 1995; 14:1176-86.

[151] Patapoutian A, Yoon JK, Miner JH, Wang S, Stark K, Wold B. Disruption of the mouse MRF4 gene identifies multiple waves of myogenesis in the myotome. Development. 1995;121:3347-58.

[152] Olson EN, Arnold HH, Rigby PW, Wold BJ. Know your neighbors: Three phenotypes in null mutants of the myogenic bHLH gene MRF4. Cell. 1996;85:1-4.

[153] Cooper RN, Tajbakhsh S, Mouly V, Cossu G, Buckingham $\mathrm{M}$, Butler-Browne GS. In vivo satellite cell activation via Myf5 and MyoD in regenerating mouse skeletal muscle. J Cell Sci. 1999;112 (Pt 17):2895-901. 
[154] Kelly RG, Zammit PS, Schneider A, Alonso S, Biben C, Buckingham ME. Embryonic and fetal myogenic programs act through separate enhancers at the MLC1F/3F locus. Dev Biol. 1997;187:183-99.

[155] Zammit PS, Cohen A, Buckingham ME, Kelly RG. Integration of embryonic and fetal skeletal myogenic programs at the myosin light chain $1 \mathrm{f} / 3 \mathrm{f}$ locus. Dev Biol. 2008;313:420-33.

[156] Ferrari G, Cusella-De Angelis G, Coletta M, et al. Muscle regeneration by bone marrow-derived myogenic progenitors. Science. 1998;279:1528-30.

[157] Heslop L, Beauchamp JR, Tajbakhsh S, Buckingham ME, Partridge TA, Zammit PS. Transplanted primary neonatal myoblasts can give rise to functional satellite cells as identified using the Myf5nlacZl+ mouse. Gene Ther. 2001;8:778-83.

[158] Volkmann R. Über die Regeneration des quergestreiften Muskelgewebes beim Menschen und Säugethier. Beitr path Anat 1893;12:233-332.

[159] Neerunjun JS, Dubowitz V. Identification of regenerated dystrophic minced muscle transplanted in normal mice. J Neurol Sci. 1975;24:33-8.

[160] Snow MH. Myogenic cell formation in regenerating rat skeletal muscle injured by mincing. II. An autoradiographic study. Anat Rec. 1977;188:201-17.

[161] Snow MH. An autoradiographic study of satellite cell differentiation into regenerating myotubes following transplantation of muscles in young rats. Cell Tissue Res. 1978; 186:535-40.

[162] Lipton BH, Schultz E. Developmental fate of skeletal muscle satellite cells. Science. 1979;205:1292-4.

[163] Bittner RE, Schofer C, Weipoltshammer K, et al. Recruitment of bone-marrow-derived cells by skeletal and cardiac muscle in adult dystrophic mdx mice. Anat Embryol (Berl). 1999;199:391-6.

[164] Le Douarin N. A biological cell labeling technique and its use in expermental embryology. Dev Biol. 1973;30:21722.

[165] Watt DJ, Lambert K, Morgan JE, Partridge TA, Sloper JC. Incorporation of donor muscle precursor cells into an area of muscle regeneration in the host mouse. J Neurol Sci. 1982;57:319-31.

[166] Partridge TA, Grounds M, Sloper JC. Evidence of fusion between host and donor myoblasts in skeletal muscle grafts. Nature. 1978;273:306-8.

[167] Peterson A, Pena S. Relationship of genotype and in vitro contractility in $\mathrm{mdg} / \mathrm{mdg}$ in equilibrium +/+ "mosaic" myotubes. Muscle Nerve. 1984;7:194-203.

[168] Law PK, Goodwin TG, Wang MG. Normal myoblast injections provide genetic treatment for murine dystrophy. Muscle Nerve. 1988;11:525-33.

[169] Partridge TA. Invited review: Myoblast transfer: A possible therapy for inherited myopathies? Muscle Nerve. 1991;14:197-212.

[170] Bulfield G, Siller WG, Wight PA, Moore KJ. X chromosome-linked muscular dystrophy $(\mathrm{mdx})$ in the mouse. Proc Natl Acad Sci U S A. 1984;81: 1189-92.

[171] Hoffman EP, Brown RH, Jr., Kunkel LM. Dystrophin: The protein product of the Duchenne muscular dystrophy locus. Cell. 1987;51:919-28.

[172] Sicinski P, Geng Y, Ryder-Cook AS, Barnard EA, Darlison MG, Barnard PJ. The molecular basis of muscular dystrophy in the mdx mouse: A point mutation. Science. 1989;244:1578-80.
[173] Partridge TA, Morgan JE, Coulton GR, Hoffman EP, Kunkel LM. Conversion of mdx myofibres from dystrophin-negative to -positive by injection of normal myoblasts. Nature. 1989;337:176-9.

[174] Negroni E, Vallese D, Vilquin JT, Butler-Browne G, Mouly $\mathrm{V}$, Trollet C. Current advances in cell therapy strategies for muscular dystrophies. Expert Opin Biol Ther. 2011;11:157-76.

[175] Wakeford S, Watt DJ, Partridge TA. X-irradiation improves mdx mouse muscle as a model of myofiber loss in DMD. Muscle Nerve. 1991;14:42-50.

[176] Beauchamp JR, Morgan JE, Pagel CN, Partridge TA. Dynamics of myoblast transplantation reveal a discrete minority of precursors with stem cell-like properties as the myogenic source. J Cell Biol. 1999;144:1113-22.

[177] Yao SN, Kurachi K. Implanted myoblasts not only fuse with myofibers but also survive as muscle precursor cells. J Cell Sci. 1993;105 (Pt 4):957-63.

[178] Gross JG, Morgan JE. Muscle precursor cells injected into irradiated mdx mouse muscle persist after serial injury. Muscle Nerve. 1999;22:174-85.

[179] Blaveri K, Heslop L, Yu DS, et al. Patterns of repair of dystrophic mouse muscle: Studies on isolated fibers. Dev Dyn. 1999;216:244-56.

[180] Montarras D, Morgan J, Collins C, et al. Direct isolation of satellite cells for skeletal muscle regeneration. Science. 2005;309:2064-7.

[181] Quinn LS, Holtzer H, Nameroff M. Generation of chick skeletal muscle cells in groups of 16 from stem cells. Nature. 1985;313:692-4.

[182] Quinn LS, Nameroff M, Holtzer H. Age-dependent changes in myogenic precursor cell compartment sizes. Evidence for the existence of a stem cell. Exp Cell Res. 1984; $154: 65-82$.

[183] Quinn LS, Norwood TH, Nameroff M. Myogenic stem cell commitment probability remains constant as a function of organismal and mitotic age. J Cell Physiol. 1988;134:32436.

[184] McGeachie JK, Grounds MD. Initiation and duration of muscle precursor replication after mild and severe injury to skeletal muscle of mice. An autoradiographic study. Cell Tissue Res. 1987;248:125-30.

[185] Grounds MD, McGeachie JK. A model of myogenesis in vivo, derived from detailed autoradiographic studies of regenerating skeletal muscle, challenges the concept of quantal mitosis. Cell Tissue Res. 1987;250:563-9.

[186] Grounds MD, McGeachie JK. Myogenic cells of regenerating adult chicken muscle can fuse into myotubes after a single cell division in vivo. Exp Cell Res. 1989;180:42939.

[187] Molnar G, Ho ML, Schroedl NA. Evidence for multiple satellite cell populations and a non-myogenic cell type that is regulated differently in regenerating and growing skeletal muscle. Tissue Cell. 1996;28:547-56.

[188] Baroffio A, Hamann M, Bernheim L, Bochaton-Piallat ML, Gabbiani G, Bader CR. Identification of selfrenewing myoblasts in the progeny of single human muscle satellite cells. Differentiation. 1996;60:47-57.

[189] Rantanen J, Hurme T, Lukka R, Heino J, Kalimo H. Satellite cell proliferation and the expression of myogenin and desmin in regenerating skeletal muscle: Evidence for two different populations of satellite cells. Lab Invest. 1995;72:341-7.

[190] Schultz E. Satellite cell proliferative compartments in growing skeletal muscles. Dev Biol. 1996;175:84-94. 
[191] Schultz E, Gibson MC, Champion T. Satellite cells are mitotically quiescent in mature mouse muscle: An EM and radioautographic study. J Exp Zool. 1978;206:451-6.

[192] Yoshida N, Yoshida S, Koishi K, Masuda K, Nabeshima Y. Cell heterogeneity upon myogenic differentiation: Downregulation of MyoD and Myf-5 generates 'reserve cells'. J Cell Sci. 1998;111 (Pt 6):769-79.

[193] Zammit PS, Golding JP, Nagata Y, Hudon V, Partridge TA, Beauchamp JR. Muscle satellite cells adopt divergent fates: A mechanism for self-renewal? J Cell Biol. 2004;166:347-57.

[194] Kuang S, Kuroda K, Le Grand F, Rudnicki MA. Asymmetric self-renewal and commitment of satellite stem cells in muscle. Cell. 2007;129:999-1010.

[195] Hoh JF, Hughes S. Myogenic and neurogenic regulation of myosin gene expression in cat jaw-closing muscles regenerating in fast and slow limb muscle beds. J Muscle Res Cell Motil. 1988;9:59-72.

[196] Hoh JF, Hughes S. Basal lamina and superfast myosin expression in regenerating cat jaw muscle. Muscle Nerve. 1991;14:398-406.

[197] Pavlath GK, Thaloor D, Rando TA, Cheong M, English AW, Zheng B. Heterogeneity among muscle precursor cells in adult skeletal muscles with differing regenerative capacities. Dev Dyn. 1998;212:495-508.

[198] Feldman JL, Stockdale FE. Skeletal muscle satellite cell diversity: Satellite cells form fibers of different types in cell culture. Dev Biol. 1991;143:320-34.

[199] Dell'Orso S, Juan AH, Ko KD, et al. Single cell analysis of adult mouse skeletal muscle stem cells in homeostatic and regenerative conditions. Development. 2019;146.

[200] Giordani L, He GJ, Negroni E, et al. High-Dimensional Single-Cell Cartography Reveals Novel Skeletal MuscleResident Cell Populations. Mol Cell. 2019;74:609-621 e6.

[201] Forcina L, Cosentino M, Musaro A. Mechanisms Regulating Muscle Regeneration: Insights into the Interrelated and Time-Dependent Phases of Tissue Healing. Cells. 2020;9.

[202] Panci G, Chazaud B. Inflammation during post-injury skeletal muscle regeneration. Semin Cell Dev Biol. 2021.

[203] St Pierre BA, Tidball JG. Differential response of macrophage subpopulations to soleus muscle reloading after rat hindlimb suspension. Journal of Applied Physiology. 1994;77:290-7.

[204] Papadimitriou JM, Robertson TA, Mitchell CA, Grounds MD. The process of new plasmalemma formation in focally injured skeletal muscle fibers. Journal of Structural Biology. 1990;103:124-34.

[205] Orimo S, Hiyamuta E, Arahata K, Sugita H. Analysis of inflammatory cells and complement $\mathrm{C} 3$ in bupivacaineinduced myonecrosis. Muscle Nerve. 1991;14:515-20.

[206] Robertson TA, Maley MA, Grounds MD, Papadimitriou JM. The role of macrophages in skeletal muscle regeneration with particular reference to chemotaxis. Exp Cell Res. 1993;207:321-31.
[207] Cantini M, Massimino ML, Bruson A, Catani C, Dalla Libera L, Carraro U. Macrophages regulate proliferation and differentiation of satellite cells. Biochem Biophys Res Commun. 1994;202:1688-96.

[208] Cantini M, Carraro U. Macrophage-released factor stimulates selectively myogenic cells in primary muscle culture. J Neuropathol Exp Neurol. 1995;54:121-8.

[209] Lescaudron L, Peltekian E, Fontaine-Perus J, et al. Blood borne macrophages are essential for the triggering of muscle regeneration following muscle transplant. Neuromuscul Disord. 1999;9:72-80.

[210] Joe AW, Yi L, Natarajan A, et al. Muscle injury activates resident fibro/adipogenic progenitors that facilitate myogenesis. Nat Cell Biol. 2010;12:153-63.

[211] Grounds MD. Skeletal muscle precursors do not arise from bone marrow cells. Cell Tissue Res. 1983;234:713-22.

[212] Goodell MA, Brose K, Paradis G, Conner AS, Mulligan RC. Isolation and functional properties of murine hematopoietic stem cells that are replicating in vivo. J Exp Med. 1996;183:1797-806.

[213] Gussoni E, Soneoka Y, Strickland CD, et al. Dystrophin expression in the mdx mouse restored by stem cell transplantation. Nature. 1999;401:390-4.

[214] De Angelis L, Berghella L, Coletta M, et al. Skeletal myogenic progenitors originating from embryonic dorsal aorta coexpress endothelial and myogenic markers and contribute to postnatal muscle growth and regeneration. J Cell Biol. 1999;147:869-78.

[215] Negroni E, Bigot A, Butler-Browne GS, Trollet C, Mouly V. Cellular Therapies for Muscular Dystrophies: Frustrations and Clinical Successes. Hum Gene Ther. 2016;27:117-26.

[216] Cossu G, Previtali SC, Napolitano S, et al. Intra-arterial transplantation of HLA-matched donor mesoangioblasts in Duchenne muscular dystrophy. EMBO Molecular Medicine. 2015;7:1513-28.

[217] Takahashi K, Yamanaka S. Induction of pluripotent stem cells from mouse embryonic and adult fibroblast cultures by defined factors. Cell. 2006;126:663-76.

[218] Chal J, Al Tanoury Z, Hestin M, et al. Generation of human muscle fibers and satellite-like cells from human pluripotent stem cells in vitro. Nat Protoc. 2016;11:1833-50.

[219] Mauro A, Shafiq SA, Mihorat AT, eds. Regeneration of Skeletal Muscle and Myogenesis. 1970, Exerpta Medica: Amsterdam.

[220] Mauro A, ed. Muscle Regeneration. 1979, Raven Press: New York.

[221] Bader CR, Bertrand D, Cooper E, Mauro A. Membrane currents of rat satellite cells attached to intact skeletal muscle fibers. Neuron. 1988;1:237-40.

[222] Griggs RC, Karpati G, eds. Myoblast Transfer Therapy. 1990, Plenum Press: New York. 